The Cryosphere Discuss., https://doi.org/10.5194/tc-2019-9

Manuscript under review for journal The Cryosphere

Discussion started: 20 February 2019

(C) Author(s) 2019. CC BY 4.0 License.

\title{
Assessing snow cover changes in the Kola Peninsula, Arctic Russia, using a synthesis of MODIS snow products and station observations.
}

\author{
Rebecca M. Vignols ${ }^{1,2}$, Gareth J. Marshall ${ }^{1}$, W. Gareth Rees ${ }^{2}$, Yulia Zaika ${ }^{3}$, Tony Phillips ${ }^{1}$, Ilona Blinova ${ }^{4}$ \\ ${ }^{1}$ British Antarctic Survey, Cambridge, CB3 0ET, UK \\ $5 \quad$ 'Scott Polar Research Institute, University of Cambridge, CB2 1ER, UK \\ ${ }^{3}$ Moscow State University Khibiny Research and Education station, Kirovsk, 184230, Russia \\ ${ }^{4}$ Polar Alpine Botanical Garden-Institute, Kirovsk, 184230, Russia
}

Correspondence to: Rebecca M. Vignols (regnos32@bas.ac.uk)

Abstract. The very high albedo of snow means that changes in its coverage have a significant impact on the Earth's global energy budget. Thus, Northern Hemisphere snow cover, which comprises approximately $98 \%$ of the global total area of seasonal snow, is responsible for the largest annual and inter-annual contrasts in land surface albedo. Here, we examine recent changes in snow cover (2000-2016) in the western mountain regions (hereinafter WMR) of the Kola Peninsula in Arctic Russia, an area that has undergone significant climate change in recent decades. Future changes in snow cover have the potential to have a major socio-economic impact in this region, which is primarily dependent on mining and tourism for its economy. We

15 used a combination of remote sensing data, the first time it has been used to assess snow cover in this region, and meteorological observations in our analysis. The snow cover products were processed to maximise the number of cloud-free days. First and last days of snow cover were derived for each year from snow depth observations at meteorological stations. MODIS-derived snow cover dates were compared to these station-derived dates to look for systematic biases in the satellite data. We find that for $85.8 \%$ of pixels investigated the deviation between the MODIS-derived and station-derived snow cover start and end dates

20 is less than 20 days. These 'locally calibrated' MODIS data were then used in combination with data from meteorological stations to determine the trends and variability in the duration of the snow season in the WMR in the past half century. Snow cover was found to be highly variable both spatially and at inter-annual timescales. Overall, the duration of the snow season decreased at higher altitudes and increased in valleys and plains. High spatial variability in trends in the snow cover season and snow depth across the region can be partially explained by the effect of orography and wind scouring. Between 2000 and

25 2016, opposing trends in the duration of the snow cover season occur at different stations within the WMR, though more consistent trends appear over a 25-year common interval wherein the snow cover duration has decreased statistically significantly at four of five stations. Finally, MODIS is shown to provide a highly reliable snow dataset for assessing regional snow cover changes, being able to identify correctly the only statistically significant trend observed at meteorological station. 
The Cryosphere Discuss., https://doi.org/10.5194/tc-2019-9

Manuscript under review for journal The Cryosphere

Discussion started: 20 February 2019

(c) Author(s) 2019. CC BY 4.0 License.

\section{Introduction}

30 Snow cover has a direct impact on human life in many parts of the world. It affects engineering, irrigation, travel, recreation, hydrology, while associated floods and avalanches can pose significant natural hazards (Robinson et al., 1993; Tedesco, 2015). For example, 90\% of the annual water supply in the Colorado Rockies results from snowfall (Singh and Gan, 2000) and, in Norway, where $98 \%$ of electricity production comes from hydropower, $50 \%$ of the input flow is derived from melted snow (Storvold et al., 2006). Snow also affects mountainous ecosystems and plant survival (e.g. Keller et al., 2005).

Snow is the largest component of the terrestrial cryosphere by area (e.g. Lemke et al., 2007) and 98\% of seasonal snow is located in the Northern Hemisphere (NH) (Armstrong and Brodzik, 2001), with the proportion of snow-covered land ranging from 7 to $40 \%$ over an annual cycle (Singh and Gan, 2000). With its low thermal conductivity, snow also effectively insulates the underlying soil, which means it affects permafrost extent (Zhang, 2005; Lawrence and Slater, 2010; Gouttevin et al., 2012).

In addition, snow has more indirect effects, though no less important, through its physical characteristics. Snow has high albedo, high infra-red emissivity and low thermal conductivity. Therefore, it has a strong impact on the Earth's energy balance by altering the energy flux between the atmosphere and the material beneath the snow (e.g. Dewey, 1977; Walland and Simmonds, 1997; Vavrus, 2007; Field et al., 2014). Importantly, snow's albedo leads to a positive feedback loop. Fresh snow has a very high albedo, meaning it reflects radiation back out to space, thus maintaining a cool Earth's surface. As snow melts from a warming of the atmosphere, more radiation can be absorbed by the surface, leading to further warming and so more snow melt. Snow albedo is the third most important climate feedback after water-vapour and cloud feedbacks (e.g. Bony et al., 2006).

Another important aspect of snow is its interactions with vegetation. Snowmelt is often the source of water that enables the survival and governs the productivity of vegetation (Fagre et al., 2003; Trujillo et al., 2012). Additionally, the thermal barrier caused by thick snow cover may reduce or even prevent soil frost, thus protecting plants during winter. However, too much snow in spring will tend to negatively affect plants by reducing the growing season length. Conversely, vegetation itself may also have an impact on snow cover (Broxton et al., 2014). Indeed, tree canopies can intercept significant amounts of falling snow in forested environments. This snow may then sublimate before reaching the snowpack on the ground (Essery et al., 2003; Molotch et al., 2007). In contrast, increased shrub vegetation captures and holds more snow, and may thus lengthen the snow-covered period and extend the supply of melt-water (Vajda et al., 2006).

For these many reasons, the timing of snowfall and snow cover persistence are very important parameters, and it is essential to have a good understanding of how snow has been changing over the past decades and how it is likely to change over the next century. Arctic snow is especially likely to be affected by climate change as a result of Arctic Amplification: the Arctic has warmed faster than anywhere else on the planet (Serreze et al., 2009; Serreze and Barry, 2011) and climate

60 projections suggest that this is likely to continue (IPCC, 2014). Several factors are believed to contribute to the amplification (Cohen et al., 2014) including the decline in terrestrial spring snow cover (Serreze and Barry, 2011; Matsumura et al., 2014). 
The Cryosphere Discuss., https://doi.org/10.5194/tc-2019-9

Manuscript under review for journal The Cryosphere

Discussion started: 20 February 2019

(c) Author(s) 2019. CC BY 4.0 License.

Studying arctic snow is problematic due to its high spatial variability (Liston, 2004) and the relative scarcity of ground-based measurements. Studies looking at changes in snow over the past century have focussed predominantly on the trends in snow cover extent. These trends have been negative across the Northern Hemisphere as a whole for the past few decades (e.g. Dye,

65 2002; Lemke et al., 2007, Peng et al., 2013), especially in spring (Brown and Robinson, 2011). Tedesco and Monaghan (2009) noted that, in the 1979 to 2008 interval, the duration of the melt season in the Northern Hemisphere was shortening by 6.0 days/decade. However, these are the large-scale trends and at a smaller, regional, scale, snow cover trends are not uniform and have greater inter-annual variability (Robinson and Frei, 2000; Bormann et al., 2018).

Decreases in both snow depth and snow water equivalent have been observed in North America, in contrast to

70 increases in these two parameters across much of Eurasia until 1980, after which they started to decline in parts of this region too (Bulygina et al., 2009; Shmakin, 2010; Callaghan et al., 2011). For example, Gregow et al. (2008), in their study of the impacts of climate change on snow- and wind-induced risk to Finnish forests, found that the risk of heavier snow loads increased during 1961-2000. Another example of regional variability in the response of snow cover to climate change is an increase in the number of snow-covered days each year in China since 2000, where the average snow depth increased annually despite snow depth decreasing in all seasons but spring (Huang et al., 2016). This study also emphasizes the significant regional differences in the variation of snow cover in China. Due to such high spatial and temporal variability in the response of snow cover to climate change, studying snow cover at a regional level is clearly essential.

Here, we focus on the western mountain regions (hereinafter WMR) of the Kola Peninsula in Arctic Russia (see Fig 1.). Temperatures in Russia are rising faster than average, especially in its northern Arctic regions (Olofinskaya et al., 2009).

80 The WMR, as defined for this paper, contains both lower elevation plains and the highest orography of the Kola Peninsula. The definition of these high altitude areas is based on Blinova and Chmielewski (2014): three main high altitude areas are included in the WMR (see Fig. 1) and these are the Khibiny Mountains (1,191 m), the Lovozero Mts (1,120 m) and the combined Volchji (955 m), Monche (965 m) and Chuna Tundras (1,114 m) hereafter the VMC Tundras (Blinova and Chmielewski, 2014). These mountains are extremely rich in mineral resources and also make the WMR a popular winter sports

85 tourist destination, making it a very economically valuable Russian region. The work in this paper follows on from a strong culture of Russian snow research in North-West Russia (e.g. Kitaev et al., 2007) and in the Khibiny Mountains (Glazovskaya, 2000; Sapunov et al 2006; Troshkina et al., 2005; Troshkina et al., 2009; Vikulina, 2009; Zyuzin et al., 2006), mainly focussing on snow microphysics and avalanche processes. This regional Russian snow research was summarised in 2013 with a comprehensive analysis of past changes in the Khibiny Mountains (Zaika et al., 2013). In addition to this, some papers 90 published in English have studied past climatic variations in the area (Kozlov and Berlina, 2002; Demin and Zyuzin, 2006; Demin and Zyuzin, 2009; Blinova and Chmielewski, 2014; Marshall et al., 2016) but none specifically focussed on snow cover. This work distinguishes itself by its wider spatial scope, comparing the snow cover in the mountains to the surrounding region, and, importantly, is the first to use remotely-sensed snow cover data to add to the availability of data from meteorological stations in the area. 
The Cryosphere Discuss., https://doi.org/10.5194/tc-2019-9

Manuscript under review for journal The Cryosphere

Discussion started: 20 February 2019

(c) Author(s) 2019. CC BY 4.0 License.

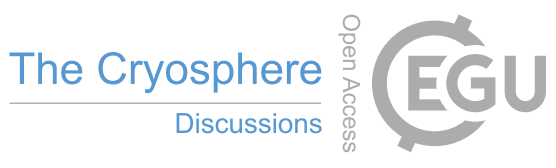

(c) (i)

The Moderate Resolution Imaging Spectroradiometer (MODIS) snow cover product has been used to study snow cover changes in many regions (Zhang et al., 2010; Dietz et al., 2012; Huang et al., 2016; Malnes et al., 2016). Here, we describe the first analysis to employ MODIS NDSI snow cover data to study snow cover in the WMR of the Kola Peninsula. The MODIS snow product lends itself well to snow cover studies within mountainous regions due to its high spatial (500 m) and temporal (daily) resolution (Bormann et al., 2018). We use a method based on Malnes et al. (2016), who processed the

100 daily MODIS snow product using multi-temporal interpolation to eliminate cloud effects and derived the first and last snowfree day in northern Norway between 2000 and 2010. In this paper we demonstrate that this method is applicable to other Arctic regions and, with a longer time series of MODIS data available to us, we are able to develop the methodology further by utilising the output to analyse recent trends in WMR snow cover from 2000-2016.

In Sect. 2, we provide a brief introduction to the climate of the WMR, including a summary of the current

105 understanding of the region's snow cover. In the following Sect. 3, the methods employed in this analysis are detailed, focussing on the validation of the MODIS data and the processing used to derive MODIS snow cover maps. In Sect.4, the results are summarised and discussed: trends in the snow cover start (SCS), snow cover end (SCE) and snow cover duration (SCD) are given for all of the available meteorological stations as well as SCS, SCE and SCD datasets of the entire WMR derived from MODIS data. Finally, Sect. 5 comprises the conclusions. 
The Cryosphere Discuss., https://doi.org/10.5194/tc-2019-9

Manuscript under review for journal The Cryosphere

Discussion started: 20 February 2019

(c) Author(s) 2019. CC BY 4.0 License.
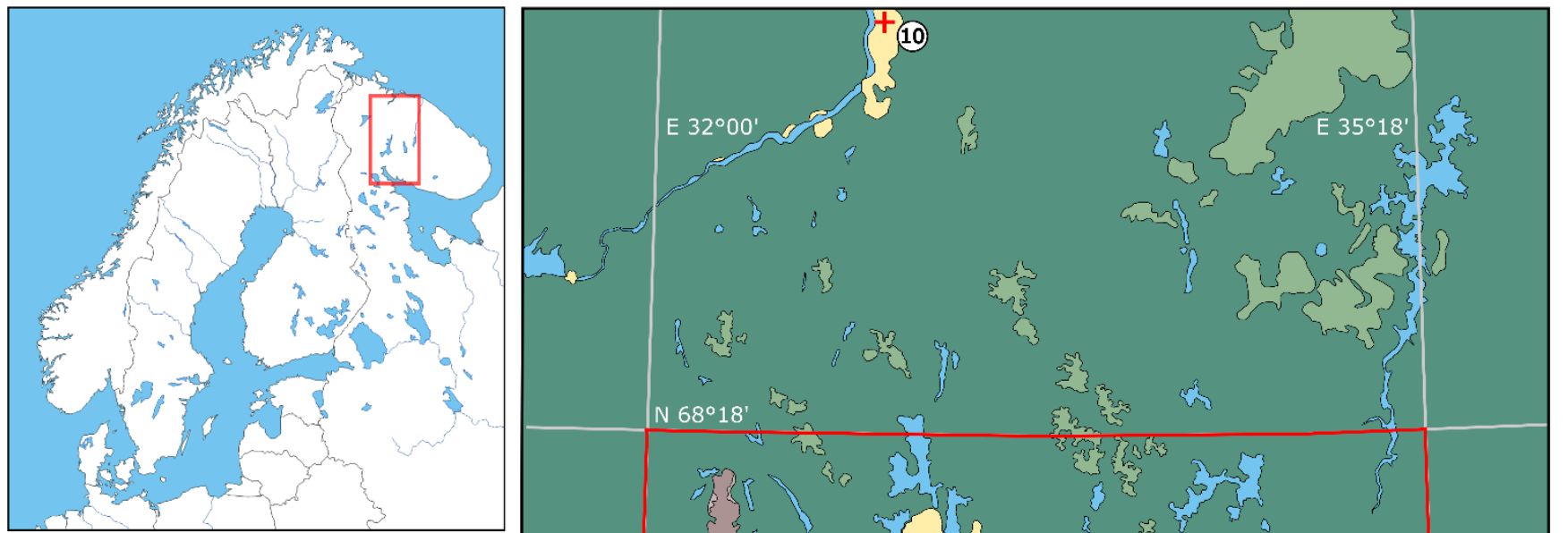

\begin{tabular}{|c|c|}
\hline & $\begin{array}{l}\text { Mountain valleys - coincident with } \\
\text { vegetation line }\end{array}$ \\
\hline & Mountains \\
\hline & Water bodies \\
\hline & Infrastructure \\
\hline & Plains - vegetated \\
\hline & Low topography - unvegetated \\
\hline 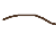 & Ridge-line approximations \\
\hline+ & Stations with snow data available \\
\hline (1) & Station number \\
\hline A & High altitude area label \\
\hline
\end{tabular}

WMR stations:

1. Monchegorsk Station

2. Apatitovaya Station

3. PABGI Station

4. MSU Khibiny Station

5. Centralnaya Station

6. Lovozero Station

Additional stations:
7. Kandalaksha Station
8. Kovda Station
9. Umba Station
10. Murmansk Station

\begin{tabular}{|l|}
\hline High altitude areas: \\
A. VMC Tundras \\
B. Khibiny Mountains \\
C. Lovozero Mountains \\
\hline
\end{tabular}

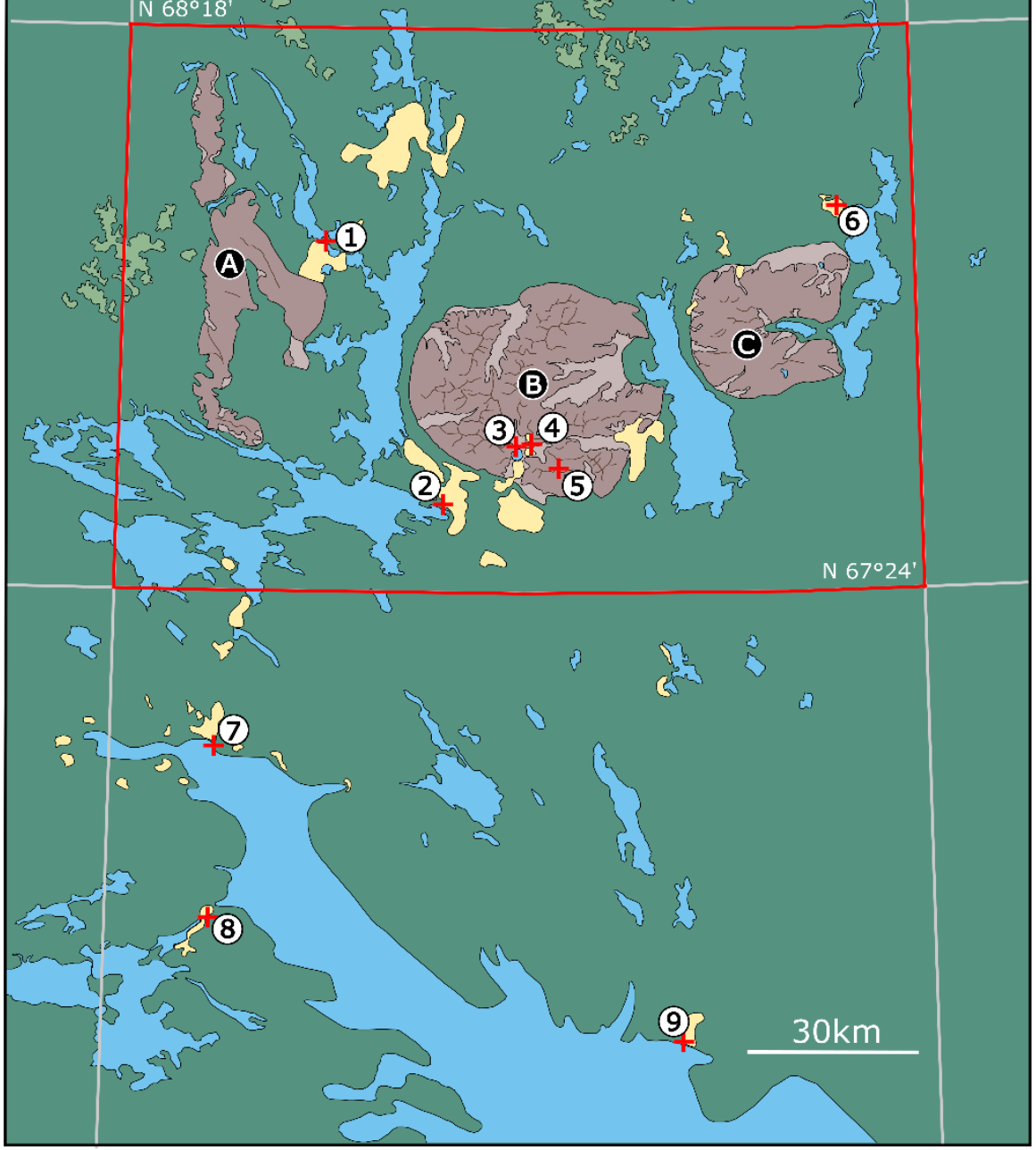

Figure 1: Map showing the WMR and its location on a map of Fennoscandia. The WMR is the area delimited in red by the four grid lines. Red crosses show the locations of the ten meteorological stations with readily available snow data. 
The Cryosphere Discuss., https://doi.org/10.5194/tc-2019-9

Manuscript under review for journal The Cryosphere

Discussion started: 20 February 2019

(c) Author(s) 2019. CC BY 4.0 License.

The WMR (see Fig. 1) is part of Murmansk Oblast (Region) $\left(66-70^{\circ} \mathrm{N}\right)$, which essentially comprises the Kola

115 Peninsula. Almost all of the Murmansk Region is situated north of the Arctic Circle, but the Gulf Stream makes its climate milder than in nearby areas east of the Kola Peninsula (Blinova and Chmielewski, 2014). A number of papers have analysed climatological trends in the Kola Peninsula (Anisimov and Reneva, 2006; Demin, 2012; Demin et al., 2014; Demin et al., 2015; Blinova and Chmielewski, 2014; Marshall et al., 2016).

The Kola Peninsula is climatically heterogeneous. The regional mean annual air temperature is $\sim{ }^{\circ} \mathrm{C}$ (Marshall et al 2016) and falls to $-2{ }^{\circ} \mathrm{C}$ in the WMR (Blinova and Chmielewski, 2014) due to higher average altitude and the lack of warming oceanic influence. The snow cover period extends from the middle of October until the end of May, and the thermal growing season from early June until the middle of September (Koroleva, 1994; Blinova and Chmielewski, 2008; Blinova, 2011). Annual surface air temperature in the Kola Peninsula has increased by $2.3 \pm 1.0{ }^{\circ} \mathrm{C}$ over the past 50 years. Seasonally, statistically significant warming has taken place in spring and autumn, although the largest trend has occurred in winter (Marshall et al., 2016). Spring has become significantly wetter and autumn drier, though annual precipitation has not undergone any significant change (Marshall et al., 2016). There has also been an overall trend towards stronger winds (Roshydromet, 2005). Within the WMR, at the highest altitudes of the Khibiny Mountains, air temperature increased in all the seasons by 0.22 to $0.54^{\circ} \mathrm{C}$ per decade between 1965 and 2015 (Demin and Volkov, 2017).

Using phenology (the study of the seasonal development of plants), Kozlov and Berlina (2002) find that the length of

130 the summer in the Kola Peninsula decreased by 15 to 20 days in the 1930 to 1998 interval. This is supported by the $44 \%$ increase in winter precipitation recorded over the Northern taiga forests in the Kola Peninsula (Høgda et al., 2001). However, Bulygina et al. (2009) argue that snow cover duration has been decreasing in north-west Russia since 1966. Additionally, Blinova and Chmielewski (2014) demonstrated shifts in the timing of the growing season and its mean prolongation by 18.5 days in the 1951 to 2012 interval. In this period, the onset of the growing season advanced by 1.1 days/decade, while the end

135 was extended by 1.8 days/decade. This matches the pattern observed in Fennoscandia but it has not been detected in the rest of Europe (Karlsen et al., 2009; Høgda et al., 2013). In this paper, we try to reconcile these opposing findings by focusing in on the rate of change of the snow season and its spatial variability in the WMR.

\section{Data and methods}

\subsection{Station data}

\subsubsection{WMR stations}

There are six meteorological stations with readily available snow data in the WMR (see Table 1), although only two of these stations have a record that covers the entire period of MODIS availability (2000-2016). Data from the Khibiny Avalanche service is difficult to obtain and, as a result, we only use the maximum annual snow depth recorded at Centralnaya between 1962 and 2005, as used by Zaika et al. (2013). It is worth noting throughout this study that snow depth measurements 
The Cryosphere Discuss., https://doi.org/10.5194/tc-2019-9

Manuscript under review for journal The Cryosphere

Discussion started: 20 February 2019

(c) Author(s) 2019. CC BY 4.0 License.

145 from the stations within higher altitude areas (MSU Khibiny and PABGI Khibiny) are likely affected by false precipitation issues as a result of wind-blown snow (Demin, personal communication). However, as this paper focuses on spatial and temporal changes in snow distribution rather than snow depth, this markedly lessens the impact of such errors on our findings.

\begin{tabular}{|c|c|c|c|c|c|}
\hline Station Name & Latitude $\left({ }^{\circ} \mathrm{N}\right)$ & Longitude $\left({ }^{\circ} \mathrm{E}\right)$ & $\begin{array}{l}\text { Elevation } \\
\text { (m) }\end{array}$ & Dates & Data used in this study \\
\hline Apatitovaya & 67.55 & 33.36 & 135 & 2010 - present & Daily snow depth. \\
\hline Centralnaya & 67.63 & 33.88 & 1050 & $1962-2005$ & $\begin{array}{l}\text { Yearly maximum snow } \\
\text { depth. }\end{array}$ \\
\hline Lovozero & 68.00 & 35.03 & 162 & 1992 - present & Daily snow depth. \\
\hline Monchegorsk & 67.97 & 32.88 & 131 & 2005 - present & Daily snow depth. \\
\hline $\begin{array}{l}\text { Moscow State } \\
\text { University (MSU) } \\
\text { Khibiny Research and } \\
\text { Education }\end{array}$ & 67.64 & 33.72 & 330 & $1984-2016$ & $\begin{array}{l}\text { Monthly average and } \\
\text { maximum snow depth. } \\
\text { And snow cover start and } \\
\text { end dates. }\end{array}$ \\
\hline $\begin{array}{l}\text { Polar-Alpine Botanical } \\
\text { Garden Institute } \\
\text { (PABGI) - Khibiny }\end{array}$ & 67.64 & 33.67 & 310 & $1991-2014$ & Monthly snow depth. \\
\hline
\end{tabular}

Table 1: Description of the WMR stations and available snow depth data.

\subsubsection{Western Murmansk Region stations}

150 Snow depth data from additional stations with longer records in the western Murmansk Region (Table 2) are used for the validation of the MODIS data (Sect. 3.3.2) and for a wider understanding of snow cover changes in the western Kola Peninsula.

\begin{tabular}{lccccc}
\hline \multicolumn{1}{c}{ Station Name } & Latitude $\left({ }^{\circ} \mathrm{N}\right)$ & Longitude $\left({ }^{\circ} \mathrm{E}\right)$ & $\begin{array}{c}\text { Elevation } \\
(\mathrm{m})\end{array}$ & Dates & Data used in this study \\
\hline Kandalaksha & 67.13 & 32.43 & 40 & $1936-$ present & Daily snow depth. \\
Kovda & 66.70 & 32.88 & 18 & $2005-$ present & Daily snow depth. \\
Murmansk & 68.98 & 33.09 & 96 & $1945-$ present & Daily snow depth. \\
Umba & 66.68 & 34.35 & 1 & 1966 - present & Daily snow depth. \\
\hline
\end{tabular}

Table 2: Description and available snow depth data of the four additional stations used in this study, the western Murmansk Region stations.

Station observations were checked for gross errors by simply plotting the data. Potentially incorrect values in the 21st century

155 were cross-checked against other available sources (e.g. https://rp5.ru) and changed if confirmed as incorrect. Earlier likely incorrect values and recent values where a more likely alternative could not be located were considered to be missing data. 
The Cryosphere Discuss., https://doi.org/10.5194/tc-2019-9

Manuscript under review for journal The Cryosphere

Discussion started: 20 February 2019

(c) Author(s) 2019. CC BY 4.0 License.

However, very few values were removed in this process so it will not have significantly impacted the calculated trends. Snow depth observations at the stations were made to the nearest centimetre.

\subsection{MODIS}

\subsubsection{General information}

The satellite data used in this study comprise the MODIS snow product from both satellites: Terra (MODIS/Terra Snow Cover Daily L3 Global 500m Grid, Version 6) and Aqua (MODIS/Aqua Snow Cover Daily L3 Global 500m Grid, Version 6). These datasets were downloaded from http://reverb.echo.nasa.gov/reverb on 21/02/17. Data were used from their earliest availability, 2000 for Terra and 2001 for Aqua, until August 31 $1^{\text {st }}$ 2016, taken as the end of the 2015/2016 snow cover season. The specific dataset used in this study is the Normalised Difference Snow Index (NDSI) snow cover dataset. This is a snow cover index that directly relates to the presence of snow in a pixel and is a more accurate description of snow detection compared to Fractional Snow Cover (FSC) products (https://nsidc.org/). NDSI is calculated from the MODIS bands 4 (B4) and 6 (B6):

(1) $\quad$ NDSI $=(\mathrm{B} 4-\mathrm{B} 6) /(\mathrm{B} 4+\mathrm{B} 6)$

Salomonson and Appel (2004) present various equations relating NDSI and FSC. Since the span of these equations includes the simple 1:1 correspondence (FSC $\approx$ NDSI), we simply adopt the NDSI as a straightforward proxy for FSC.

\subsubsection{Data processing}

The MODIS data were processed for long-term trend analysis. Before any data processing, the Aqua and Terra data comprised $52.6 \%$ and $50.97 \%$ cloud cover respectively. Merging both datasets together is the first step to replacing cloudy pixels with snow cover data (Dietz et al., 2012, Foppa and Seiz, 2012; Husler et al., 2014; Malnes et al., 2016). As the satellites have slightly different overpass times, a cloudy pixel in the data of one of the satellites may contain NDSI data in the other. For each pixel, each day, if there existed an NDSI value in one of the Aqua or Terra data sets, then this value was inserted. If a value existed in both satellite data sets then the average of the two was used. When a pixel had no value in either Aqua or Terra, a weighted average of the two nearest values within the previous five and following five days from either satellite was used to determine an NDSI value. If only one value could be found pre- or post- empty pixel, then this value was applied. Using this technique, over half of missing NDSI data were filled and the resulting combined dataset comprises only $23 \%$ missing data as a result of cloud cover.

The first and last snow-free days for each year in the 2000 to 2016 interval were calculated following the method used by Malnes et al. (2016). A cutoff value for the NDSI data of 50 (equivalent to $50 \%$ pixel FSC) was taken to evaluate the start and end of the snow cover. The snow cover start (SCS) is defined as the first day when a $50 \%$ FSC value is reached for more than 5 days in a row. The snow cover end (SCE) is defined as the first snow-free day when an FSC value falls below 50 
The Cryosphere Discuss., https://doi.org/10.5194/tc-2019-9

Manuscript under review for journal The Cryosphere

Discussion started: 20 February 2019

(c) Author(s) 2019. CC BY 4.0 License.

\% for more than 10 days in a row. This difference in cutoff time is due to the high cloud cover in autumn which hinders MODIS' snow cover retrieval ability over longer periods of time than in spring.

Earliest and latest SCS and SCE dates were set for the analysis (Malnes et al., 2016). These dates were selected based on snow cover start and end dates at stations and on the dates of the Polar night in the region (Dec $2^{\text {nd }}$ to January $10^{\text {th }}$ ) to avoid problems due to low solar angles. The SCS was set as being able to occur between September $1^{\text {st }}$ and November $17^{\text {th }}$. The SCE was set as being able to occur between March $15^{\text {th }}$ and August $31^{\text {st }}$. The snow cover duration (SCD) is the number of days with snow cover and the MODIS SCD dates were calculated from the SCS and SCE maps, following equation 2, with DiY being the number of days in the year (365 or 366).

(2) $\mathrm{SCD}=(\mathrm{DiY}-\mathrm{SCS})+(\mathrm{SCE}-1)$ (as the end of snow cover is the first day with no snow)

\section{Results and Discussion}

\subsection{Station data}

\subsubsection{Snow cover depth}

Plots of daily snow cover depth at the Apatitovaya, Lovozero and Monchegorsk stations located in the WMR for the entirety of their available record (see Table 3) are shown in Fig. 2. The inter-annual range in snow depth at these three stations is considerable, especially for the two latter stations, with longer records. The largest inter-annual differences in snow depth can be seen at the end of the snow season. For example, in some years, such as 2016/17, the snow depth was at its highest peak or only just starting to melt out at the time of the median SCE (Figure 2). Thus at Lovozero station, the highest inter-annual depth range can be seen in late April when the snow depth ranges from 0 to $88 \mathrm{~cm}$. However, at Apatitovaya and Monchegorsk stations the maximum inter-annual difference is observed in early May, where the range is just over and just under $80 \mathrm{~cm}$, respectively. Note that late season snowfall can be observed at Lovozero station, where a renewed snow depth peak appears at the end of the snow season. This is not seen at the other two stations but is likely to be simply a result of the longer record at Lovozero station, as all late season snowfall on record there occurred between 1996 and 2001.

The inter-annual difference in SCS and SCE dates at these three stations is also clearly seen in these figures and is summarized in Table 3.

\begin{tabular}{|c|c|c|c|}
\hline Station & Dates of available data & SCS inter-annual variability & SCE inter-annual variability \\
\hline Apatitovaya & $2011-2017$ & October $13^{\text {th }}-$ November $5^{\text {th }}$ & 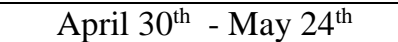 \\
\hline Lovozero & $1992-2017$ & October $1^{\text {st }}-$ November $5^{\text {th }}$ & April $22^{\text {nd }}$ and June $6^{\text {th }}$ \\
\hline Monchegorsk & $2005-2017$ & October $14^{\text {th }}$ - November $16^{\text {th }}$ & April $30^{\text {th }}-$ June $4^{\text {th }}$ \\
\hline
\end{tabular}

Table 3: Inter-annual differences in SCS and SCE dates at the Apatitovaya, Lovozero and Monchegorsk stations. 
The Cryosphere Discuss., https://doi.org/10.5194/tc-2019-9

Manuscript under review for journal The Cryosphere

Discussion started: 20 February 2019

(c) Author(s) 2019. CC BY 4.0 License.

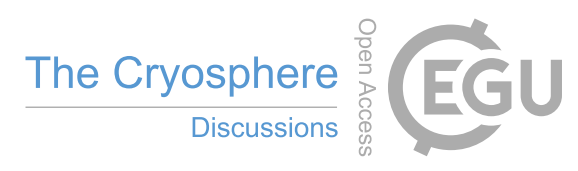

(c) (i)
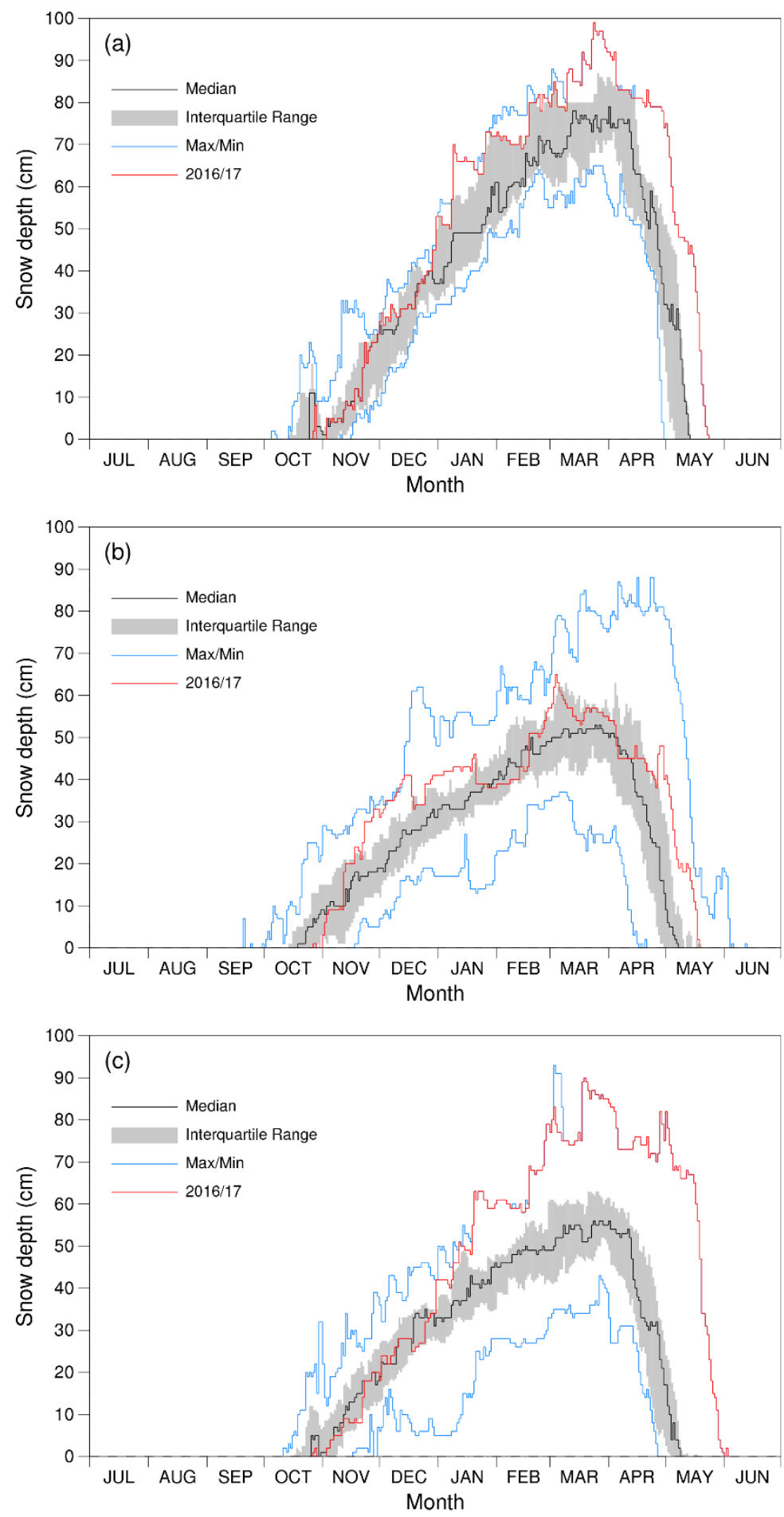

Figure 2: Snow depth range at (a) Apatitovaya station, (b) Lovozero station, (c) Monchegorsk station. 
The Cryosphere Discuss., https://doi.org/10.5194/tc-2019-9

Manuscript under review for journal The Cryosphere

Discussion started: 20 February 2019

(c) Author(s) 2019. CC BY 4.0 License.

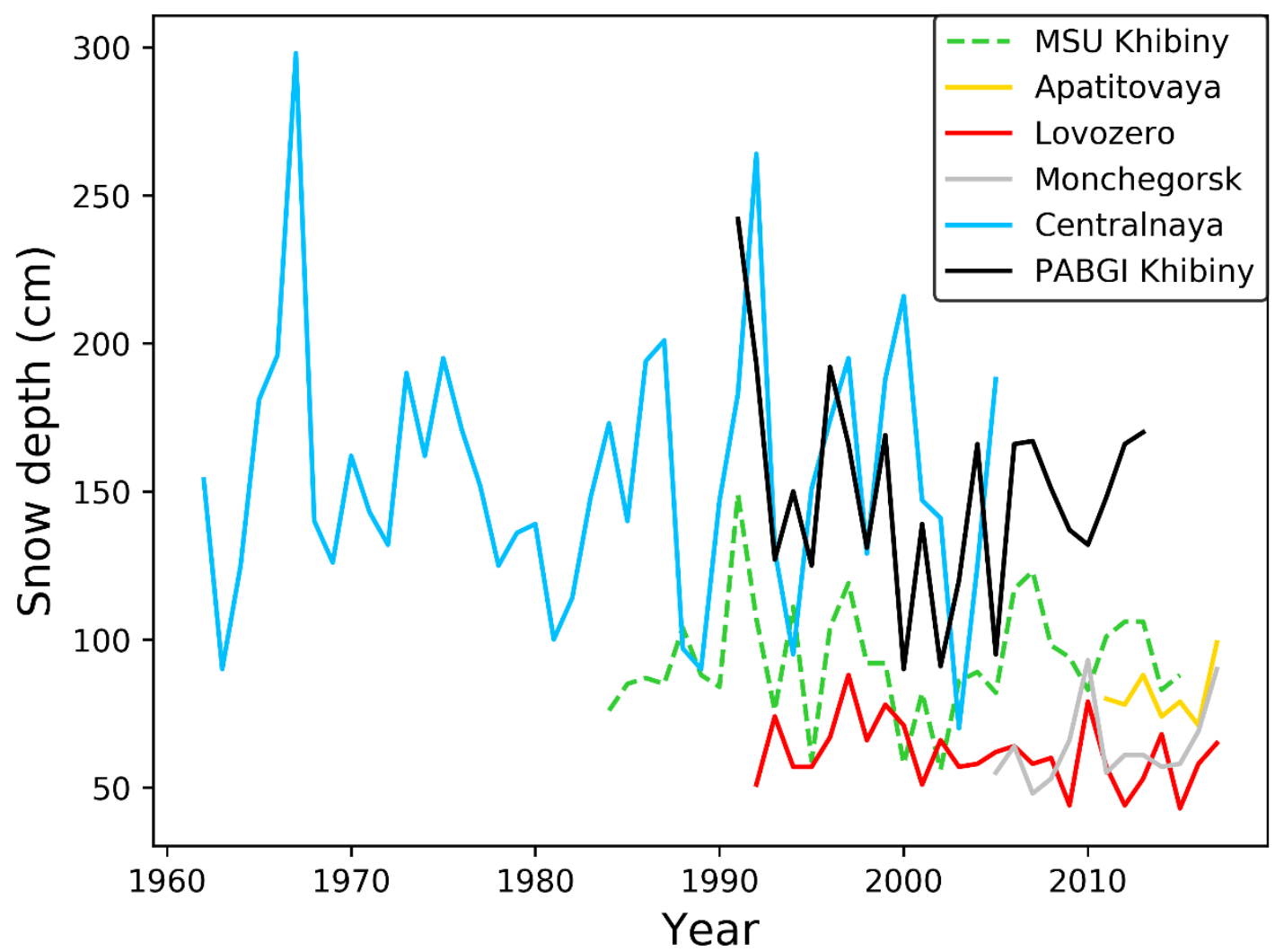

Figure 3: Maximum snow depth in centimetres at the Centralnaya station, MSU Khibiny station, PABGI Khibiny station, Lovozero station, Monchegorsk station and Apatitovaya station. The data from Centralnaya station was collected by the Khibiny avalanche service.

Figure 3 shows a comparison of yearly maximum snow depth at all six stations from the WMR used in this study.

The maximum snow depth at the stations within the Khibiny Mountains (Centralnaya, PABGI Khibiny and MSU Khibiny stations) is on average higher than those in the surrounding plains (Apatitovaya, Lovozero and Monchegorsk stations). The station at the highest altitude, Centralnaya station, also has the greatest snow depth. Over the common period of 1991 to 2005, the yearly average maximum snow depth is $13.3 \mathrm{~cm}$ deeper than at PABGI Khibiny station. At Centralnaya station, maximum snow depth varies markedly, from 100 to $300 \mathrm{~cm}$, between 1962 and 2005 but does not have a statistically significant trend over this long time period. This inter-annual variability in snow depth is likely explained by differences in air temperature, wind speed and solid precipitation (Demin, personal communication). The inter-annual variability in maximum snow depth is less for stations at lower altitudes, and there are no statistically significant trends here either.

It is interesting to compare the MSU Khibiny and PABGI Khibiny stations, as both are at similar altitudes in valleys within the Khibiny Mountains and are located only $2 \mathrm{~km}$ apart. Yearly maximum snow depth is consistently much higher at PABGI Khibiny station than for MSU Khibiny station, by $56.5 \mathrm{~cm}$ on average. This is likely explained by wind scouring. The 
The Cryosphere Discuss., https://doi.org/10.5194/tc-2019-9

Manuscript under review for journal The Cryosphere

Discussion started: 20 February 2019

(c) Author(s) 2019. CC BY 4.0 License.

(c) (i)

MSU Khibiny station is situated at a highly exposed point in the central-east valley, to the east of the largest lake in the mountains. In contrast to this, the PABGI Khibiny station is located on the lee side of the western Khibiny Mountains and has more cover from surrounding vegetation, and, as such, is shielded from the predominant westerly winds. This spatial variability in snow depth shows the importance of orography and other local factors in determining snow cover characteristics in the 235 WMR.

\subsubsection{Seasonal snow cover trends}

\subsubsection{Full time series}

\begin{tabular}{|c|c|c|c|}
\hline Station & Dates of available data & Parameter & $\begin{array}{c}\text { Trend } \\
\text { full time series } \\
\text { (days/decade) }\end{array}$ \\
\hline \multirow[t]{3}{*}{ Apatitovaya } & $2011-2017$ & SCS & -1.7 \\
\hline & & SCE & 11.1 \\
\hline & & SCD & 11.4 \\
\hline \multirow[t]{3}{*}{ Lovozero } & $1992-2017$ & SCS & 3.8 \\
\hline & & SCE & -4.4 \\
\hline & & SCD & $-9.4^{* *}$ \\
\hline \multirow[t]{3}{*}{ Monchegorsk } & $2005-2017$ & SCS & -5.1 \\
\hline & & SCE & -3.6 \\
\hline & & SCD & 2.9 \\
\hline \multirow[t]{3}{*}{ MSU Khibiny } & $1984-2016$ & SCS & -2.3 \\
\hline & & SCE & 2.4 \\
\hline & & SCD & 4.6 \\
\hline \multirow[t]{3}{*}{ Kandalaksa } & $1936-2017$ & SCS & -1.0 \\
\hline & & SCE & $1.2^{* * *}$ \\
\hline & & SCD & $2.3 * * *$ \\
\hline \multirow[t]{3}{*}{ Murmansk } & $1945-2017$ & SCS & -0.4 \\
\hline & & SCE & $1.8 * *$ \\
\hline & & SCD & $2.9 * *$ \\
\hline \multirow[t]{3}{*}{ Umba } & $1966-2017$ & SCS & 1.9 \\
\hline & & SCE & $-2.8^{* * *}$ \\
\hline & & SCD & $-5.4 * * *$ \\
\hline
\end{tabular}

Table 4: Trends in days per decade, and their significance, of the Snow Cover Start (SCS), Snow Cover End (SCE) and Snow Cover Duration (SCD) at the WMR and the western Murmansk Region stations over both their full available time-series and the MODIS common period (2000-2016). Statistically significant trends are marked with asterisks: $*=\mathbf{p}<0.1, * *=\mathbf{p}<0.05, * * *=p<0.01$.

From the daily snow depths recorded at the meteorological stations, we calculated the start, end and duration of each snow season (see Table 4). Over the 2005 to 2017 interval of data collected at Monchegorsk, the snow cover season has not undergone any statistically significant trends. However, over the time period also covered by MODIS (2005 to 2016), a statistically significant trend is identified in the SCE $(\mathrm{p}<0.01)$, wherein the snow cover season has been ending earlier at a 
The Cryosphere Discuss., https://doi.org/10.5194/tc-2019-9

Manuscript under review for journal The Cryosphere

Discussion started: 20 February 2019

(c) Author(s) 2019. CC BY 4.0 License.

rate of 1.45 days/decade. This is a result of the year 2017 being a very anomalous year (see Fig. 2), thus the inclusion of such an outlier year decreases the statistical significance of the trend. Data from the MSU Khibiny station shows a notable increase in the duration of the snow cover season since the start of the record in 1984, but none of the trends at MSU Khibiny are statistically significant. Finally, the Lovozero data shows an increasingly early start and end of the snow free season over the past 25 years, but only the trend in its SCD is statistically significant $(\mathrm{p}<0.05)$ : the SCD has been shortening by 9.4 days/decade since 1992.

It is also interesting to look at trends at some of the longer datasets in the western Kola Peninsula in order to set the trends in the WMR in a longer temporal context (see Table 4). The daily snow depth dataset from Kandalaksha station is one of the longest available from the region and shows significant trends in SCE and SCD since 1936: overall the snow season has lengthened by 2.3 days/decade. At Murmansk station, the trends in the SCE and SCD are significant over the entire timeseries. The snow cover season has been lengthening over the past 71 years at the rate of 2.9 days/decade. The SCS has changed very little over time (-0.4 days/decade; not statistically significant), so the extension of the snow cover season is primarily due to a much later end to the average snow cover season (1.8 days days/decade; significant at $\mathrm{p}<0.05$ ). At Umba station, in contrast, the snow cover season has been getting shorter over the past 39 years, at the rate of 5.4 days/decade. The delay in the start of the snow cover is not statistically significant, however the increasingly early end to the snow cover season (-2.8 days/decade) is ( $\mathrm{p}<0.01)$.

\subsubsection{25-year common time series}

By comparing changes in snow cover variability at the WMR stations to those in the wider western Kola Peninsula over a common period, we can relate our findings to the broader regional spatial variability. Table 5 shows the trends in the SCS, SCE and SCD over a common 25-year time interval (1992-2016) for the five stations of both the WMR and the wider western Murmansk Region with available data for that time. Data at four of the five stations show a positive trend in the SCS (increasingly late start to the snow cover), a negative trend in the SCE (increasingly early end of the snow season) and an overall decrease in the duration of the snow cover season. The station showing opposite results is MSU Khibiny station, located within the Khibiny Mountains and at a higher altitude than the other stations. Importantly, this opposite trend is also the only SCD trend that is not statistically significant. These results indicate a uniform regional signal of reduced SCD snow cover

270 across the lower altitudes of the western Murmansk Region between 1992 and 2016. They also imply an opposite trend in the snow cover season at higher altitudes, although more long-term data in the mountainous areas are needed to make robust conclusions on these higher-altitude zones. To resolve this issue, we use MODIS to obtain more spatially continuous data over the WMR in order to identify the spatial variability of the snow there.

Bulygina et al. (2009) found that snow cover duration has been decreasing in north-west Russia since 1966 and Blinova and Chmielewski (2014) demonstrated the mean growing season has been has been prolonged since 1951 in the Murmansk Region. Similar patterns have been found in Fennoscandia (Karlsen et al., 2009; Høgda et al., 2013). In contrast to these findings, using phenological evidence, Kozlov and Berlina (2002) found that the length of the summer in the Kola 
The Cryosphere Discuss., https://doi.org/10.5194/tc-2019-9

Manuscript under review for journal The Cryosphere

Discussion started: 20 February 2019

(c) Author(s) 2019. CC BY 4.0 License.

Peninsula decreased by 15 to 20 days in the 1930 to 1998 interval. Extracting the trends in the SCD at Kandalaksha station over comparable timescales to these two studies demonstrates that the contrasting conclusions of these previous studies can be explained by the different time periods analysed. Kandalaksha station shows a statistically significant lengthening of the snow cover season in the 1936 to 1998 interval of 4.5 days/decade, thus a decrease of the length of summer similar to Kozlov and Berlina (2002). In the 1966 to 2007 interval, a shortening of the snow cover season of 1.9 days/decade is found, though it is not statistically significant. This trend supports the conclusions of Bulygina et al. (2009).

\begin{tabular}{lcc}
\hline Station & Parameter & $\begin{array}{c}\text { 25-year trend } \\
\text { 1992-2016 (days/decade) }\end{array}$ \\
\hline Kandalaksha & SCS & 4.2 \\
& SCE & $-4.0^{* *}$ \\
Lovozero & SCD & $-8.2^{* * *}$ \\
& SCS & 3.8 \\
\multirow{2}{*}{ MSU Khibiny } & SCE & -4.4 \\
& SCD & $-9.4^{* *}$ \\
Murmansk & SCS & -2.9 \\
& SCE & 4.0 \\
Umba & SCD & 3.8 \\
& SCS & $6.2^{* *}$ \\
& SCE & -1.2 \\
& SCD & $-7.5^{*}$ \\
& SCS & 3.1 \\
& SCE & $-4.7^{* *}$ \\
\hline
\end{tabular}

Table 5: Trends in days per decade and their significance of the Snow Cover Start (SCS), Snow Cover End (SCE) and Snow Cover Duration (SCD) at the five stations with available data over the 25-year common interval (1992-2016). Statistically significant trends are marked with asterisks: $*=\mathbf{p}<0.1, * *=\mathbf{p}<0.05, * * *=\mathbf{p}<0.01$.

\subsection{MODIS processed datasets}

\subsubsection{Missing data}

Despite processing efforts to minimise missing data described in section 3.2.2, cloud cover remained a hindrance to the extraction of SCS, SCE and SCD dates in the WMR. The number of missing years in each of the SCS, SCE and SCD datasets are shown in Fig. 4. Pixels of missing data make up 22.6 \%, $5.9 \%$ and $24.6 \%$ of the SCS, SCE and SCD respectively. Water bodies have missing data in the SCS datasets for 12 to 16 years out of a possible 16 years. This can be explained by the fact that these areas will only return a SCS date when they have frozen over and started accumulating snow on this surface. The freezing process is slow and usually does not occur in time for the ice to be covered in snow before November $17^{\text {th }}$. In the 295 dry land section of the region, there is very little missing data in the SCE dataset and more missing data in the SCS data, especially for the plains. This is a result of the increased cloud cover in the autumn associated with the high snowfall. SCD is calculated from SCS and SCE and, as a result, has a combination of the missing data in those two datasets. 
The Cryosphere Discuss., https://doi.org/10.5194/tc-2019-9

Manuscript under review for journal The Cryosphere

Discussion started: 20 February 2019

(c) Author(s) 2019. CC BY 4.0 License.

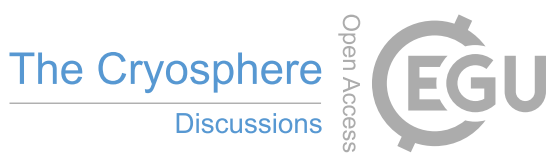

(c) (i)
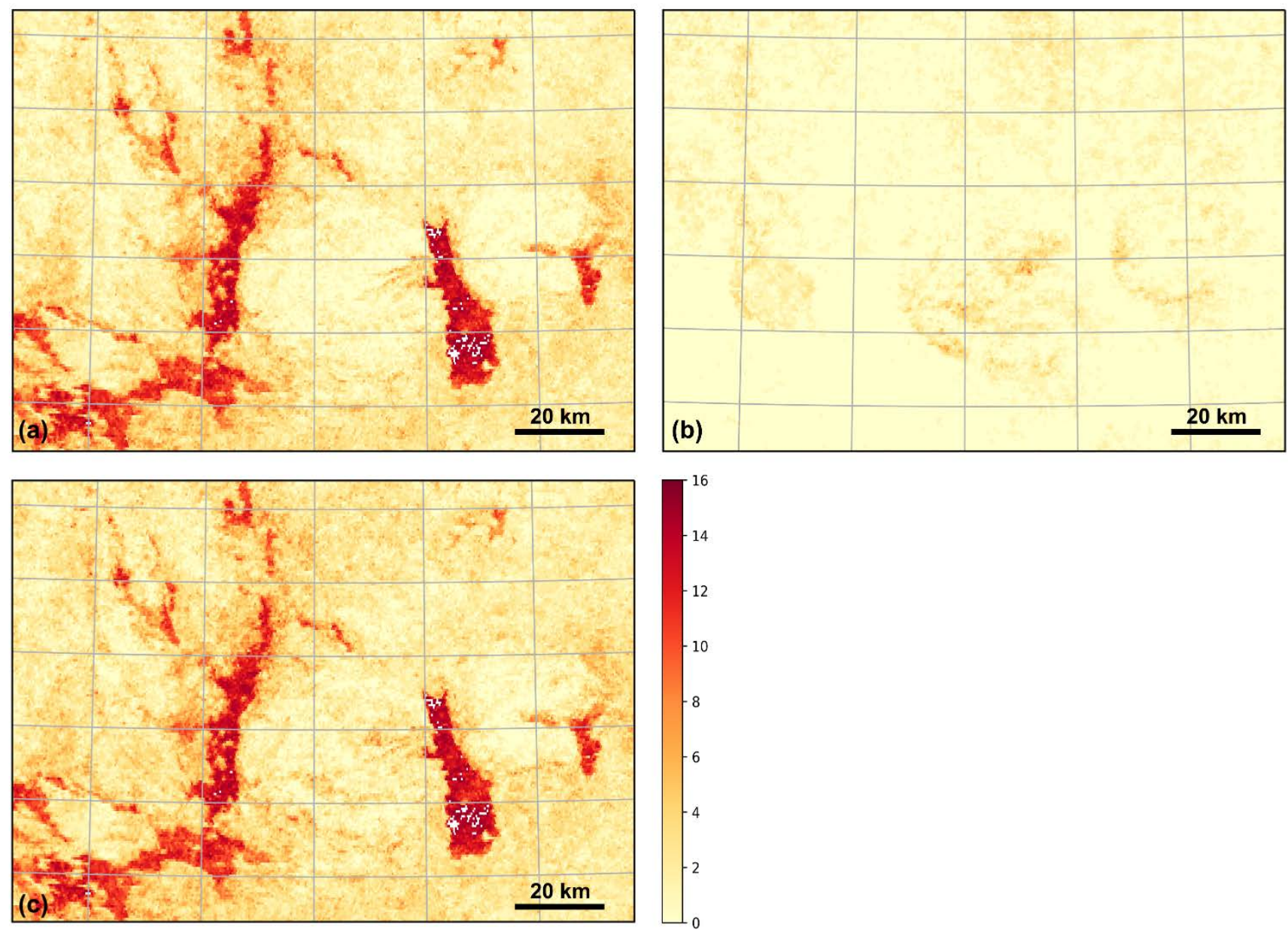

Figure 4: Number of years with missing a. SCS, b. SCE and c. SCD data over the 2000/2001 to 2015/2016 interval in the WMR.

\subsubsection{Station validation}

The MODIS data processing algorithm was tested by comparing the derived SCS and SCE dates with those recorded at meteorological stations. Only one (MSU Khibiny) recorded the start and end dates of the snow cover season, so a method of extracting SCS and SCE dates from snow depth data was used for the other stations. SCS (/SCE) was defined as the first day with more than 5 (/10) days in a row with snow cover depth higher(/lower) than 1cm at a station. SCS and SCE dates were extracted from the SCS and SCE MODIS processed datasets for each of the following stations: Apatitovaya, Lovozero, Monchegorsk, MSU Khibiny, Murmansk, Kandalaksha, Kovda and Umba. The results of the comparison of these to the station data are shown in Table 6.

The difference between the SCS and SCE end dates from station data and MODIS processing was calculated for all years at all stations. This difference is taken as the station dates minus the MODIS dates and the results are shown in Table 6. 
The Cryosphere Discuss., https://doi.org/10.5194/tc-2019-9

Manuscript under review for journal The Cryosphere

Discussion started: 20 February 2019

(c) Author(s) 2019. CC BY 4.0 License.

All annual 'maps' have missing data (see Fig. 4) and as a result, there is no MODIS data for some years at all stations. In one extreme case, no SCS dates could be extracted at all for Kandalaksha (Table 6).

\begin{tabular}{lrrrrrrrr}
\hline & \multicolumn{4}{c}{ SCS } & \multicolumn{4}{c}{ SCE } \\
\cline { 2 - 10 } & \multicolumn{1}{c}{$\begin{array}{l}\text { Mean } \\
\end{array}$} & $\begin{array}{l}\text { Mean } \\
\text { offset }\end{array}$ & $\begin{array}{l}\text { Positive or } \\
\text { negative } \\
\text { offset }\end{array}$ & $\begin{array}{l}\text { Number of } \\
\text { missing } \\
\text { years }\end{array}$ & Mean & $\begin{array}{l}\text { Mean } \\
\text { offset }\end{array}$ & $\begin{array}{l}\text { Positive or } \\
\text { negative } \\
\text { offset }\end{array}$ & $\begin{array}{l}\text { Number of } \\
\text { missing } \\
\text { years }\end{array}$ \\
\hline Apatity & -3.5 & 3.5 & Negative & 2 & 4.4 & 4.4 & Positive & 0 \\
Lovozero & -4.0 & 5.3 & Both & 4 & 11.1 & 11.1 & Positive & 1 \\
Monchegorsk & 0.7 & 10.4 & Both & 4 & 15.6 & 15.6 & Positive & 0 \\
MSU Khibiny & 7.9 & 12.4 & Both & 3 & -1.6 & 6.2 & Both & 2 \\
Murmansk & -3.6 & 10.5 & Both & 7 & -5.9 & 12.9 & Both & 6 \\
Kandalaksha & & & & 16 & 20.9 & 20.9 & Positive & 2 \\
Kovda & 7.4 & 10.4 & Both & 3 & -8.0 & 8.0 & Negative & 0 \\
Umba & -0.8 & 4.0 & Both & 7 & -0.2 & 2.8 & Both & 0
\end{tabular}

Table 6: Summary statistics of the difference between dates determined from data collected at meteorological stations and from the MODIS processed datasets in the 2000/2001 to 2015/2016 interval for the SCS and SCE. This difference is taken as the station dates minus the MODIS dates, and the unit for the mean and mean offset columns are number of days.

On average, the difference is 8.6 and 10.4 days between the station and MODIS SCS and SCE dates respectively. There is a slight bias in the MODIS dates with higher errors being positive, so finding an earlier date than the station data. On average the mean bias of the SCS and SCE dates are + 1.2 days and + 5.0 days respectively. Overall, errors are larger in the spring (SCE). This is probably a result of our methodology used to extract SCS dates combined with the higher proportion of missing data in the SCS dataset. Indeed, for times with particularly extensive cloud cover, SCS is more likely not to return a value rather than return a biased one.

In the WMR, the MODIS dates are most representative of the Apatitovaya station data. The differences are uniform and quite low for the MSU Khibiny station for the SCE, however errors are more inconsistent and reach higher values for the SCS. The Lovozero station is the opposite, with consistent low differences in the SCS dates and higher more varied differences in the SCE dates. In the WMR, the deviation between station and MODIS dates is largest at the Monchegorsk station. consistently early nor consistently late. At Kovda station, the deviation between MODIS and station data SCS is highly variable between years, reaching high values of over 30 days. The MODIS SCE dates there are all later than those recorded at the station. Kandalaksha station values follow the opposite trend with the MODIS SCS dates being much earlier than the station values for all years. The differences are highest for Kandalaksha station with an offset of up to 41 days. Though this offset is very high, it is not unprecedented. Indeed, Dietz et al (2010) found that $10 \%$ (/3 \%) of their study area was characterised by 34 to $72(/ 72+)$ days deviation between station data and MODIS SCD. In this analysis, we find that for $85.8 \%$ of pixels investigated (SCS and SCE combined) the deviation in the MODIS-derived dates is less than 20 days, $9.9 \%$ of pixels have a deviation between 20 to 30 days and only $4.3 \%$ of pixels are characterised by a deviation between 30 and 41 days (Fig. 5). 
The Cryosphere Discuss., https://doi.org/10.5194/tc-2019-9

Manuscript under review for journal The Cryosphere

Discussion started: 20 February 2019

(c) Author(s) 2019. CC BY 4.0 License.

(c) $\underset{\mathrm{BY}}{\mathrm{BY}}$

Thus, despite the large magnitude of some errors, deviation between the station data and MODIS-derived snow cover season dates are in fact lower than for some previous studies.

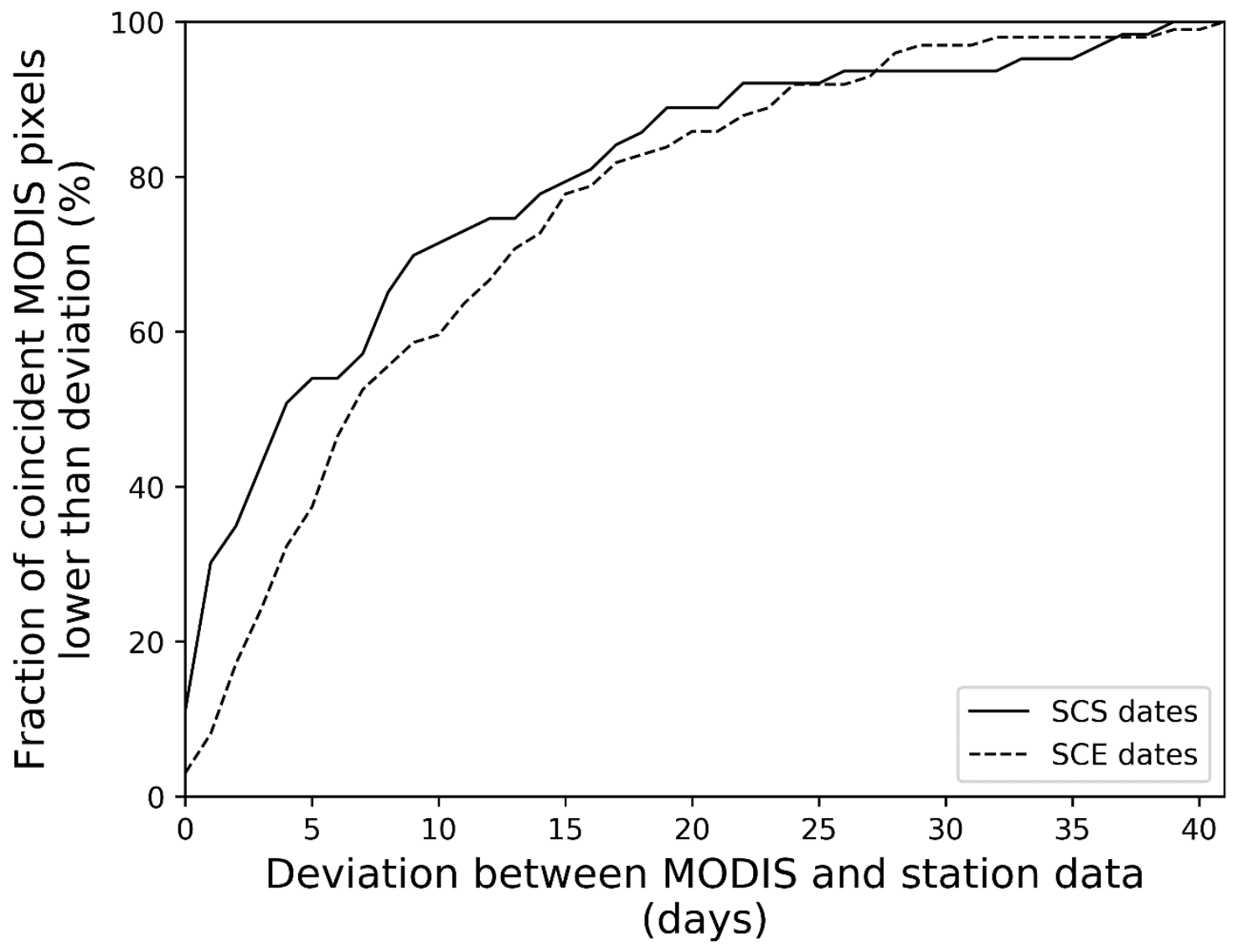

Figure 5: Graph showing the proportion of pixels with a deviation of lower than 0 to 41 days between the MODIS-derived and station data-derived SCS and SCE dates.

\subsubsection{Mean SCS, SCE and SCD}

Figure 6 shows the mean SCS, SCE and SCD dates over the entire MODIS period, 2000-2016, and illustrates the high spatial variability in the long-term snow cover distribution in the WMR.

Clear climatological differences between the mountainous areas and the surrounding plains can be seen. The snow cover season starts much earlier in the mountains than in the plains, and as expected it starts at the highest elevations first (around September $22^{\text {nd }}$ on average) and then gradually moves to lower altitudes. For most years, the delay in the SCS in the mountain valleys is $\sim 30$ days later than the highest elevations. The snow cover season then begins in the north-east of the WMR as defined in this study before arriving in the plains further south, surrounding the mountains. The SCS date for the 
The Cryosphere Discuss., https://doi.org/10.5194/tc-2019-9

Manuscript under review for journal The Cryosphere

Discussion started: 20 February 2019

(c) Author(s) 2019. CC BY 4.0 License.

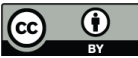

plains surrounding the higher elevations of the WMR is usually similar to those of the larger valleys within the mountains ( October $\left.21^{\mathrm{st}}\right)$.
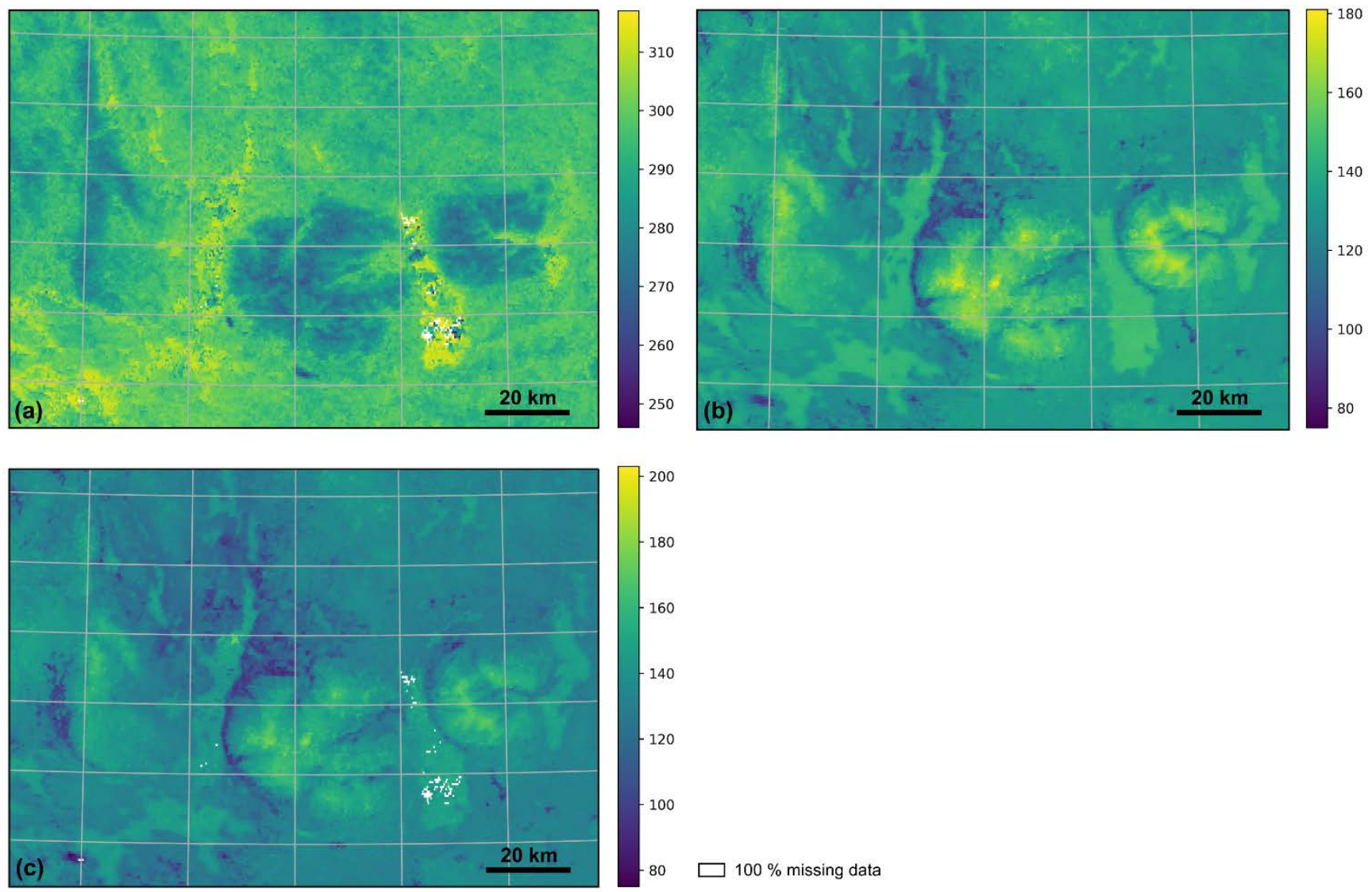

350 Figure 6: Three MODIS maps showing the (a) mean snow cover start, (b) mean snow cover end, and (c) mean snow cover duration of the WMR. Scales on (a) and (b) are the day of year, and for (c) the scale is of the number of days.

The SCS is slightly more uniform across the whole Khibiny and Lovozero mountains than the SCE, which is more gradual and follows altitude. The SCE is earliest at the lowest altitudes ( May $\left.20^{\text {th }}\right)$ while it occurs at the highest elevations around June $29^{\text {th }}$ on average. This results in a very clear link between altitude and SCD, with the highest altitudes having the longest snow cover season in the entire area ( 180 days) and the duration of the snow cover season decreasing with lowering elevation. Thus the snow season in the plains surrounding the mountains is much shorter than in the higher altitude areas (by approximately 50 days). Within the plains, the SCE is earliest on the western side of the two high mountain ranges and VMC Tundras. As a result, this area has the shortest snow cover season in the region, between 95 and 100 days long.

Finally, the water bodies have a very noticeable difference with the land around them, which sees them having a much later snow cover start than any other area in the region, but also have a later snow cover end. In 2015, the water bodies did not return snow cover end dates (see Fig. A1o in the Appendix). In most other years, the water bodies which had frozen and were 
The Cryosphere Discuss., https://doi.org/10.5194/tc-2019-9

Manuscript under review for journal The Cryosphere

Discussion started: 20 February 2019

(c) Author(s) 2019. CC BY 4.0 License.

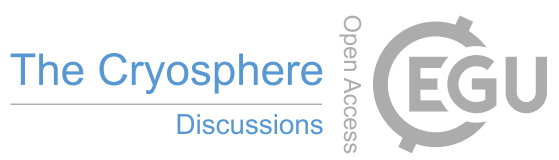

(c) $\underset{\mathrm{BY}}{\mathrm{B}}$

covered in snow, remained so until later in the year ( May $\left.30^{\text {th }}\right)$ than the surrounding plains $\left(\sim\right.$ May $\left.15^{\text {th }}\right)$. This is probably due to the snow on ice taking longer to melt out than the surrounding snow on top of ground, due to the higher heat capacity and reflectance of ice than soil.

\subsubsection{SCS, SCE and SCD inter-annual variability}
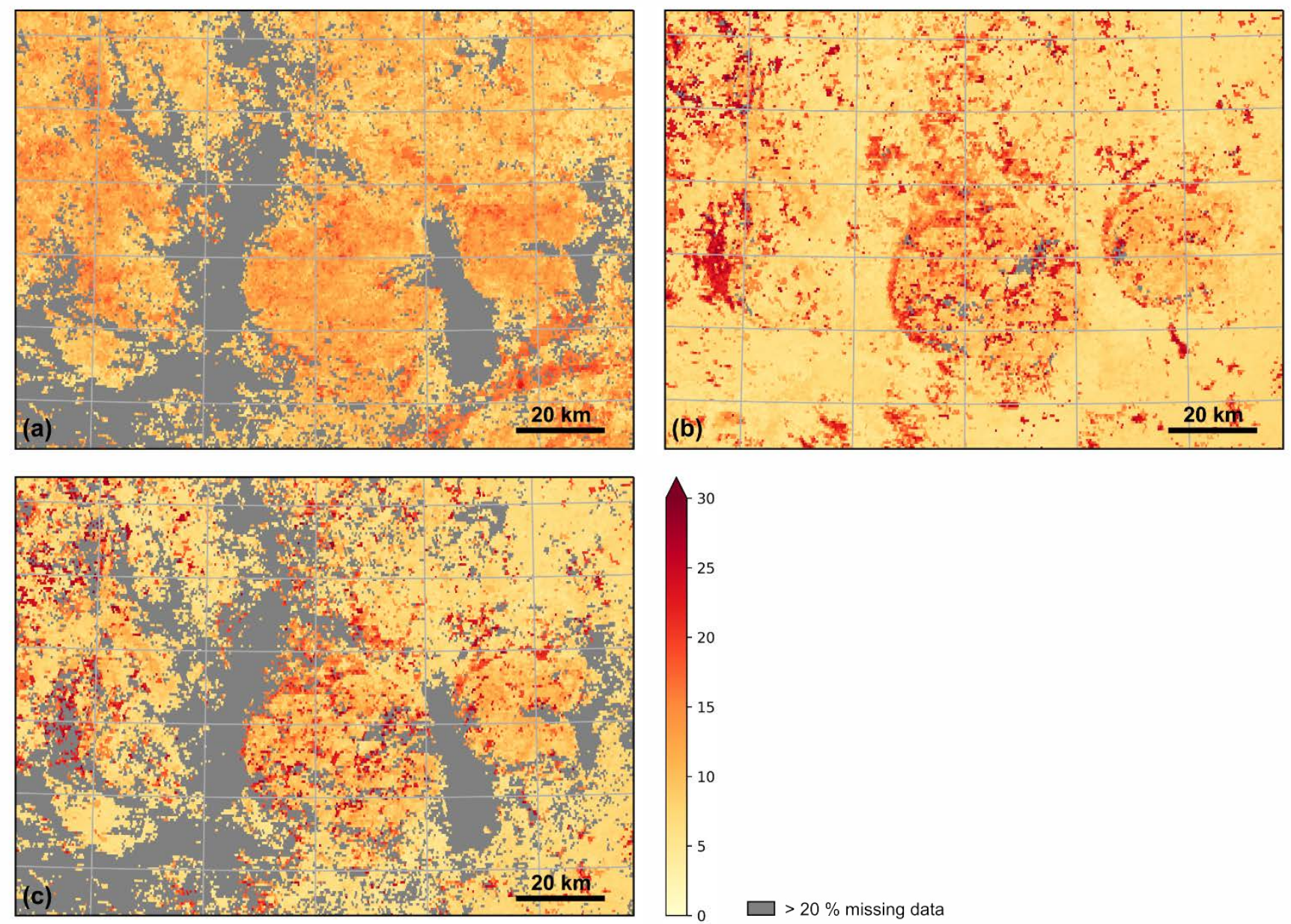

Figure 7: Standard deviation in days of the a. SCS, b. SCE and c. SCD over the 2000/2001 to 2015/2016 interval in the WMR.

Figure 7 shows the standard deviation from the mean in the SCS, SCE and SCD datasets. The two dark streaks south of the Khibiny Mountains in Fig. 7a are the result of a processing artefact in the original MODIS data in the year 2006 (see Fig. A1g in the Appendix).

Most aspects of snow cover in the WMR have been characterised by high inter-annual variability over the past few decades. Figure 8 shows this particularly clearly where the standard deviation from the mean in SCS is consistently over 15 days across the region, and where the standard deviation reaches over 30 days in many pixels in the SCE and SCD datasets. 
The Cryosphere Discuss., https://doi.org/10.5194/tc-2019-9

Manuscript under review for journal The Cryosphere

Discussion started: 20 February 2019

(c) Author(s) 2019. CC BY 4.0 License.

Overall, the standard deviation is much higher for the SCS than the SCE and SCD. Indeed, the dates of SCS vary considerably from year to year, with a very noticeable difference between the consecutive years 2008 and 2009 for example where the snow cover in the plains surrounding the mountains starts on average 20 days later in 2009 than it did in 2008 (see Fig. A1i and A1j in the Appendix). SCD is the most inter-annually uniform snow cover parameter. Station data suggests that this is a result of SCS and SCE working in the same direction, and thus counter-balancing each other. The SCD standard deviation pattern is much closer to that of SCE than SCS, as SCE standard deviation is much more spatially variable than SCS. Overall, for all three parameters the standard deviation is larger in the high-altitude areas, reaching over 30 days for SCE and SCD. The standard deviation is also high on the western edges to all topographical features in both the SCE and SCD, consistently reaching over 20 days. This is likely due to the strong relationship between westerly winds and orographic precipitation and thus snow cover. In the SCE and SCD parameters, the plains have very low standard deviations of under 10 days.

\subsubsection{Trends in SCS, SCE and SCD}

It is possible to investigate trends in the snow cover using the SCS, SCE and SCD dates extracted from the MODIS processed dataset. These can be compared to those recorded at the meteorological stations by calculating the trends over the common period of 2000-2016. Table 7 shows these trends: the only statistically significant trend is at Monchegorsk, similar to the observations, where the snow cover season has been ending 11.6 days/decade earlier (14.5 days/decade for the observations). This result, and the lack of spurious statistically significant trends at the other stations, provides further evidence that MODIS can be used to analyse snow-cover trends in the WMR with a high degree of confidence.

\begin{tabular}{|c|c|c|c|c|}
\hline Station & $\begin{array}{l}\text { Dates of common period with } \\
\text { MODIS }\end{array}$ & Parameter & $\begin{array}{c}\text { Trend } \\
\text { Station data } \\
\text { (days/decade) }\end{array}$ & $\begin{array}{c}\text { Trend } \\
\text { MODIS data } \\
\text { (days/decade) }\end{array}$ \\
\hline \multirow[t]{3}{*}{ Apatitovaya } & $2011-2016$ & SCS & -2.9 & -80.2 \\
\hline & & SCE & -7.7 & 0.8 \\
\hline & & SCD & 8.0 & 7.9 \\
\hline \multirow[t]{3}{*}{ Lovozero } & $2000-2016$ & SCS & -4.1 & -4.8 \\
\hline & & SCE & -3.4 & -1.4 \\
\hline & & SCD & 2.7 & -2.8 \\
\hline \multirow[t]{3}{*}{ Monchegorsk } & 2005 - 2016 & SCS & -9.9 & 24.2 \\
\hline & & SCE & $-14.5^{* * *}$ & $-11.6^{*}$ \\
\hline & & SCD & -5.4 & -10.7 \\
\hline \multirow[t]{3}{*}{ MSU Khibiny } & $2000-2016$ & SCS & -3.6 & 1.9 \\
\hline & & SCE & 5.3 & -1.4 \\
\hline & & SCD & 8.7 & 2.6 \\
\hline
\end{tabular}

Table 7: Trends in days per year and their significance of the Snow Cover Start (SCS), Snow Cover End (SCE) and Snow Cover Duration (SCD) at the four WMR stations from both data collected at those stations and from the MODIS processed dataset. Statistically significant trends are marked with asterisks: $*=\mathbf{p}<0.1, * *=\mathbf{p}<0.05, * * *=\mathbf{p}<0.01$. 
The Cryosphere Discuss., https://doi.org/10.5194/tc-2019-9

Manuscript under review for journal The Cryosphere

Discussion started: 20 February 2019

(c) Author(s) 2019. CC BY 4.0 License.

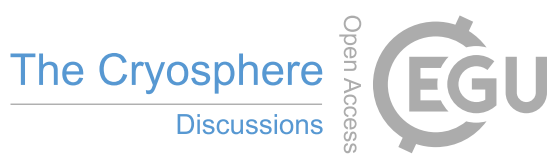

Figure 8 shows the high spatial variability of trends in snow cover in the WMR, as calculated from the MODIS processed dataset. Figure 9 shows the statistical significance of these trends, with statistically significant trends shown in colour, matching the direction of the trend.

The SCS trend figure (Fig. 8a) shows a clear orographic influence. The western side of the Khibiny Mountains has a positive SCS trend, in other words the SCS has been increasingly later in the year over the past 16 years. Conversely, the eastern side of the mountains has a negative trend of less than 20 days/decade. The snow season in the Lovozero Mountains has also started later by 10 to 20 days/decade, as has the western edge of the VMC Tundras. The proportion of statistically significant trends in these two high altitude areas however is quite low (Fig. 9a). The plains do not show a consistent trend in Fig. 8a, but the majority of the statistically significant trends there (Fig. 9a) are negative. These contradicting trends are difficult to explain, but the delay in the start of the snow season in the high altitudes is probably in part explained by the decrease in autumn precipitation in the Kola Peninsula (Marshall et al., 2016).
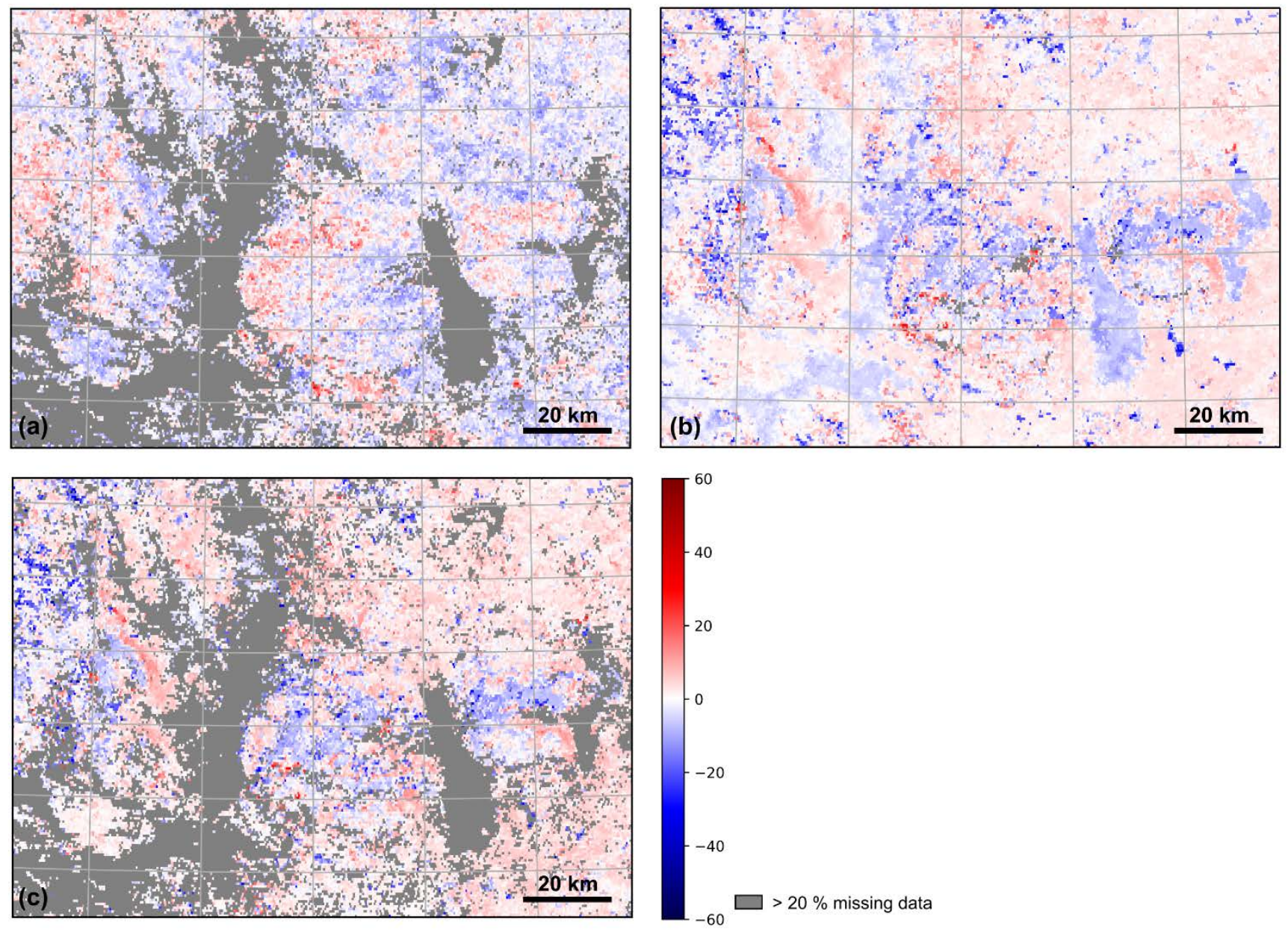

Figure 8: Trends in days per decade in the a. SCS, b. SCE and c. SCD over the 2000/2001 to 2015/2016 interval in the WMR. 
The Cryosphere Discuss., https://doi.org/10.5194/tc-2019-9

Manuscript under review for journal The Cryosphere

Discussion started: 20 February 2019

(c) Author(s) 2019. CC BY 4.0 License.

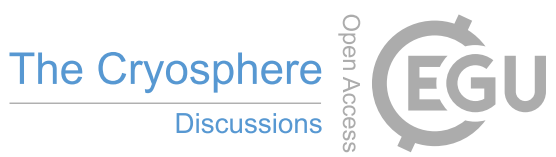

(c) (i)
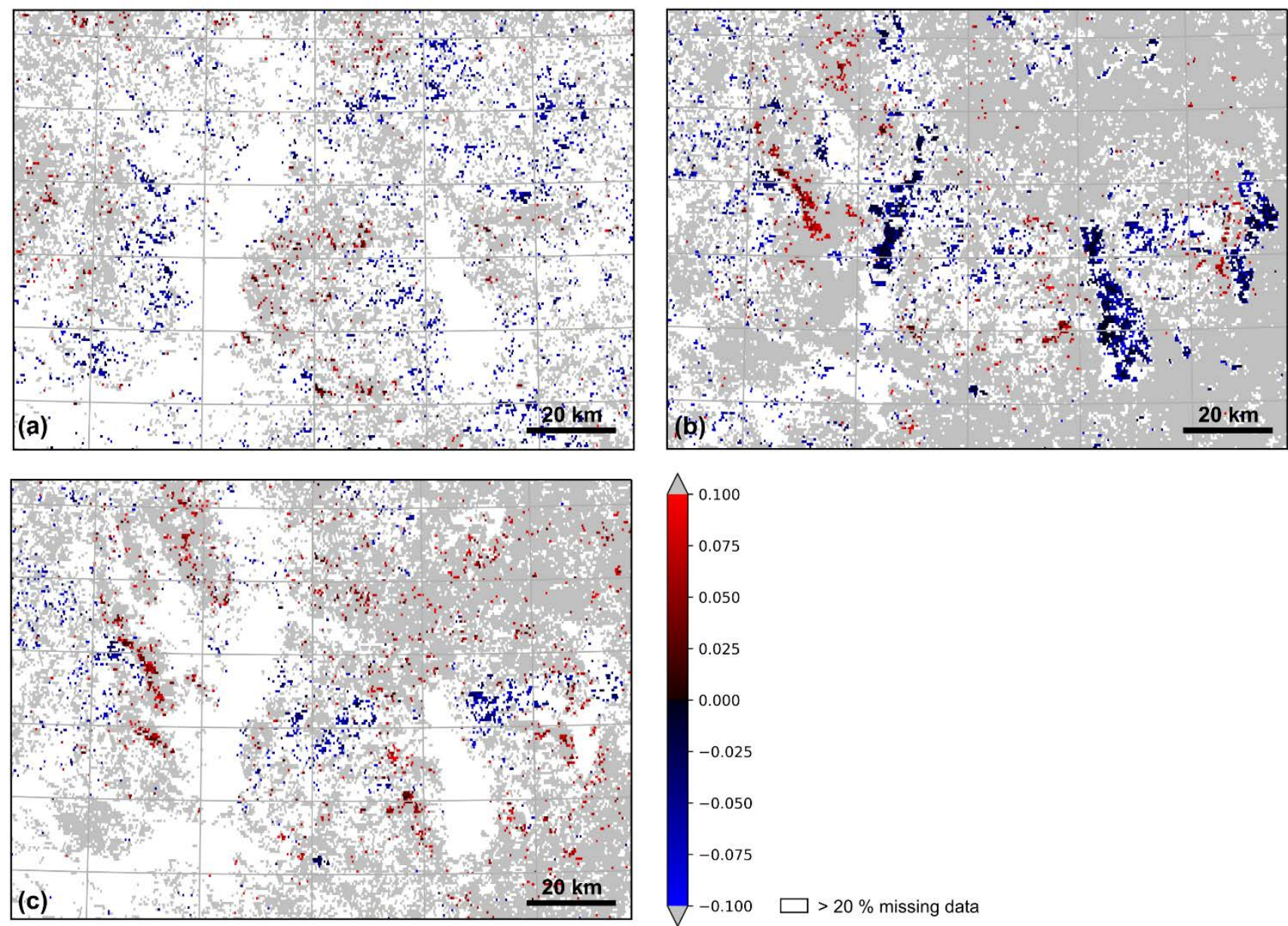

Figure 9: Statistical significance of positive (red) and negative (blue) trends in the a. SCS, b. SCE and c. SCD over the 2000/2001 to 2015/2016 interval in the WMR. Grey pixels show trends that are not statistically significant.

In Fig. 8b, the plains have a consistent positive trend in SCE (of less than 10 days/decade). These positive trends are not so dominant in Fig. 9b, as the majority of the trends in the plain are not statistically significant. However, the main clusters of significant trends in the low attitude zones are negative over water bodies and are positive along the eastern edges of the mountain ranges. These positive trends in the plains may be explained by the fact that spring has become increasingly wet (Marshall et al., 2016), so increased snowfall would delay the end of the snow season. Trends in the SCE in the higher altitude areas are not so clear in Fig. 8b. Some of the high-altitude zones have had a delay in the end of the snow cover (positive trend) and others, such as the northern Khibiny and Lovozero Mountains, have had an increasingly early SCE (negative trend). The picture becomes clearer in Fig. 9b, where it is possible to see that parts of the northern Khibiny and Lovozero Mountains as well as the VMC Tundras are characterised by statistically significant negative trends, and that the only statistically significant positive trends in SCE at high elevations are in the southern and eastern Khibiny and Lovozero Mountains. The increasingly 
The Cryosphere Discuss., https://doi.org/10.5194/tc-2019-9

Manuscript under review for journal The Cryosphere

Discussion started: 20 February 2019

(c) Author(s) 2019. CC BY 4.0 License.

420 early end to the snow cover in the higher altitudes may be due, in part, to increased blowing snow (Demin, personal communication) as a result of the overall trend towards stronger winds in the Kola Peninsula (Roshydromet, 2005).

The SCD has shortened statistically significantly by 10 to 20 days/decade within the mountains at the higher altitudes in the northern Khibiny, northern Lovozero Mountains as well as the lower elevation topography of the VMC Tundras. The very south-eastern areas of the Khibiny and Lovozero Mountains are the only regions of high elevation that have undergone statistically significant positive trends. Contrastingly, the SCD has undergone small, positive and statistically significant trends (less than 10 days/decade extension) in mountain valleys and widespread areas of the plains in the WMR. The plains to the north-west corner of the Khibiny Mountains is the only low elevation zone with an increasingly short snow cover season, due to an earlier end of the snow season by approximately 20 days/decade.

\section{Conclusions}

430 In this paper, we have used a combination of remote sensing data and meteorological observations to analyse past changes in snow cover in the WMR of the Kola Peninsula, Arctic Russia. MODIS snow products were processed in order to create SCS, SCE and SCD datasets. Although for some areas and some years, the start and end of the snow season could not be detected due to long overcast periods (Fig. 4), this MODIS post-processing reduced the number of missing pixels by more than half.

- $\quad$ MODIS is able to provide a highly reliable snow parameter dataset in the WMR of Arctic Russia. We have validated it through a comparison of the timing and trends of the snow cover season with station data. The average difference between the station data and MODIS processed dataset-derived SCS and SCE dates is 8.6 and 10.4 days respectively, both relatively low errors. In this analysis, we find that for $85.8 \%$ of pixels investigated (SCS and SCE combined) the deviation in the MODIS-derived dates is less than 20 days.

- It is possible to extract realistic trends from the MODIS processed dataset. Indeed, MODIS-extracted trends are identical to observed trends in that MODIS was able to identify the only statistically significant trend while not giving spuriously significant trends elsewhere.

- There is high inter-annual and spatial variability in the long-term snow cover trends in the WMR of the Kola Peninsula. Overall, between 2000 and 2016, the snow cover duration has been decreasing at higher altitudes and increasing at lower altitudes. The end of the snow cover season has become increasingly later in the plains that surround the WMR, but there is not such a clear trend in SCE in the higher altitude areas. Snow depth was also found to be highly spatially variable and the difference in maximum yearly snow depth was found to be over $50 \mathrm{~cm}$ between two stations (PABGI Khibiny and MSU Khibiny) only $2 \mathrm{~km}$ apart at very similar altitudes in valleys within the Khibiny Mountains. These differences in snow depth as well as some of the trends in the snow cover season are probably explained by wind scouring that occurs in the WMR. 
The Cryosphere Discuss., https://doi.org/10.5194/tc-2019-9

Manuscript under review for journal The Cryosphere

Discussion started: 20 February 2019

(c) Author(s) 2019. CC BY 4.0 License.

(c) (i)

- Three of four meteorological stations in the WMR were found to have recorded an increasingly long snow cover season across their differing length but the only statistically significant trend was negative. This spatial variability is also found to exist on larger scales over longer periods.

- Overall, six of the eight stations with daily snow data examined across the western Murmansk region over 2000-2016 recorded a lengthening of the snow cover season over their records, but only two positive trends and the two negative trends were statistically significant.

- A uniform, statistically significant, regional decrease in the duration of the snow cover season between 1992 and 2016 has occurred across the lower altitudes of the western Murmansk Region.

The next step in this work will be to link the regional snow cover variability to changes in atmospheric circulation through regional coupled model runs and, subsequently, to make predictions of future snow cover based on projected circulation changes in the main IPCC emission scenarios.

\section{Data availability}

MODIS/Terra Snow Cover Daily L3 Global 500m Grid, Version 6 and MODIS/Aqua Snow Cover Daily L3 Global 500m Grid, Version 6, available for download from http://reverb.echo.nasa.gov/reverb. Other data available by contacting the corresponding author.

\section{Author contributions}

RMV undertook the research described in this paper and prepared the manuscript with contributions from all co-authors. GJM made figure 2, RMV prepared all other figures.

\section{Competing interests}

470 The authors declare that they have no conflict of interest.

\section{Acknowledgements}

We thank Moscow State University and, especially, the team at the MSU Khibiny Research and Education station for making the fieldwork possible and for sharing data. We thank the Polar-Alpine Botanical Garden-Institute also for sharing their data. In addition, we thank Valery Demin for his comments on snow cover in the WMR. RMV is funded by the UK Natural 475 Environment Research Council (NERC) NERC Ph.D. studentship NE/L002507/1. GJM is supported by NERC through the British Antarctic Survey research program Polar Science for Planet Earth. 
The Cryosphere Discuss., https://doi.org/10.5194/tc-2019-9

Manuscript under review for journal The Cryosphere

Discussion started: 20 February 2019

(c) Author(s) 2019. CC BY 4.0 License.

\section{References}

Anisimov, O. and Reneva, S.: Permafrost and changing climate: the Russian perspective. AMBIO: A Journal of the Human Environment, 35(4), pp.169-175, https://doi.org/10.1579/0044-7447(2006)35[169:PACCTR]2.0.CO;2, 2006.

Armstrong, R.L. and Brodzik, M.J.: Recent Northern Hemisphere snow extent: A comparison of data derived from visible and microwave satellite sensors. Geophysical Research Letters, 28(19), pp.3673-3676, https://doi.org/10.1029/2000GL012556, 2001.

Atlaskina, K., Berninger, F. and de Leeuw, G.: Satellite observations of changes in snow-covered land surface albedo during spring in the Northern Hemisphere, The Cryosphere, 9(5), pp.1879-1893, https://doi.org/10.5194/tc-9-1879-2015, 2015.

Blinova, I. and Chmielewski, F.M.: Climatic warming above the Arctic Circle: are there trends in timing and length of the thermal growing season in Murmansk Region (Russia) between 1951 and 2012?. International journal of biometeorology, 59(6), pp.693-705, https://doi.org/10.1007/s00484-014-0880-y, 2014.

Blinova, I. and Chmielewski, F.M.: Subarctic warming and its influence on the growth of orchid populations in the Extreme North-East of Europe (Murmansk Region). Journal Europäischer Orchideen, 40(4), p.663, 2008.

490 Blinova, I.: The traits of seasonal development of orchid species north of the Arctic Circle. Bot Zh, 96(3), pp.396-411, 2011. (in Russian)

Bony, S., Colman, R., Kattsov, V.M., Allan, R.P., Bretherton, C.S., Dufresne, J.L., Hall, A., Hallegatte, S., Holland, M.M., Ingram, W. and Randall, D.A.: How well do we understand and evaluate climate change feedback processes?. Journal of Climate, 19(15), pp.3445-3482, 2006.

495 Bormann, K.J., Brown, R.D., Derksen, C. and Painter, T.H.: Estimating snow-cover trends from space. Nature Climate Change, 8(11), p.924., https://doi.org/10.1038/s41558-018-0318-3, 2018.

Brown, R.D. and Robinson, D.A.: Northern Hemisphere spring snow cover variability and change over 1922-2010 including an assessment of uncertainty. The Cryosphere, 5(1), pp.219-229, https://doi.org/10.5194/tc-5-219-2011, 2011.

Broxton, P.D., Harpold, A.A., Biederman, J.A., Troch, P.A., Molotch, N.P. and Brooks, P.D.: Quantifying the effects of vegetation structure on snow accumulation and ablation in mixed-conifer forests. Ecohydrology, 8(6), pp.1073-1094, https://doi.org/10.1002/eco.1565, 2014.

Bulygina, O.N., Razuvaev, V.N. and Korshunova, N.N.: Changes in snow cover over Northern Eurasia in the last few decades. Environmental Research Letters, 4(4), p.045026, https://doi.org/10.1088/1748-9326/4/4/045026, 2009.

Callaghan, T.V., Johansson, M., Brown, R.D., Groisman, P.Y., Labba, N., Radionov, V., Barry, R.G., Bulygina, O.N., Essery, 505 R.L., Frolov, D.M. and Golubev, V.N.: The changing face of Arctic snow cover: A synthesis of observed and projected changes. AMBIO: A Journal of the Human Environment, 40(sup 1), pp.17-31, https://doi.org/10.1007/s13280-011-0212-y, 2011.

Cohen, J., Screen, J.A., Furtado, J.C., Barlow, M., Whittleston, D., Coumou, D., Francis, J., Dethloff, K., Entekhabi, D., Overland, J. and Jones, J.: Recent Arctic amplification and extreme mid-latitude weather. Nature geoscience, 7(9), pp.627637, https://doi.org/10.1038/ngeo2234, 2014. 
The Cryosphere Discuss., https://doi.org/10.5194/tc-2019-9

Manuscript under review for journal The Cryosphere

Discussion started: 20 February 2019

(c) Author(s) 2019. CC BY 4.0 License.

Demin, V.I.: General climatic tendencies on the Kola Peninsula during the meteorological measurements period. Proc. Kola Sci. Cent., 1, pp.98-110, 2012. (in Russian)

Demin V.I., Antsyferova A.P., and Mokrotovarova O.I.: Changes of the air temperature in Murmansk since the $19^{\text {th }}$ century. Herald of the Kola Science Centre of the Russian Academy of Sciences, 20(1), pp.113-126, 2015. (in Russian)

515 Demin V.I., Sviashchennikov P.N., and Ivanov B.V.: Long-Term Variations of Large-Scale Atmosphere Circulation and the modern climate warming at the Kola Peninsula. Herald of the Kola Science Centre of the Russian Academy of Sciences, 17(2), pp.101-106, 2014. (in Russian)

Demin V. I. and Volkov A.V.: A comparison of air temperature trends in the Khibiny Mountains and over the surrounding plains. Fundamental and applied climatology, 3, pp.6-27, 2017. (in Russian)

520 Demin, V.I. and Zyuzin, Y.L.: On climatic changes in the Khibiny Mountains (Kola Peninsula, Russia). Physics of Auroral Phenomena, Proceedings of the XXIX Annual Seminar, Apatity, pp. 281-284, 2006.

Demin, V.I. and Zyuzin, Y.L.: Detection of the mountain ecosystem dynamics in the Khibiny by technique of comparison of modern and old photographs and its relation with climate changes. Physics of Auroral Phenomena, 31(1), pp.189-191, 2009.

Dewey, K.F.: Daily maximum and minimum temperature forecasts and the influence of snow cover. Monthly Weather Review, 105(12), pp.1594-1597, https://doi.org/10.1175/1520-0493(1977)105<1594:DMAMTF>2.0.CO;2, 1977.

Dietz, A.J., Wohner, C. and Kuenzer, C.: European snow cover characteristics between 2000 and 2011 derived from improved MODIS daily snow cover products. Remote Sensing, 4(8), pp.2432-2454, https://doi.org/10.3390/rs4082432, 2012.

Duguay, C.R., Flato, G.M., Jeffries, M.O., Ménard, P., Morris, K. and Rouse, W.R.: Ice-cover variability on shallow lakes at high latitudes: model simulations and observations. Hydrological Processes, 17(17), pp.3465-3483, https://doi.org/10.1002/hyp.1394, 2003.

Dye, D.G.: Variability and trends in the annual snow-cover cycle in Northern Hemisphere land areas, 1972-2000. Hydrological processes, 16(15), pp.3065-3077, https://doi.org/10.1002/hyp.1089, 2002.

Essery, R., Pomeroy, J., Parviainen, J. and Storck, P.: Sublimation of snow from coniferous forests in a climate model. Journal of Climate, 16(11), pp.1855-1864, https://doi.org/10.1175/1520-0442(2003)016<1855:SOSFCF>2.0.CO;2, 2003.

535 Fagre, D.B., Peterson, D.L. and Hessl, A.E.: Taking the pulse of mountains: ecosystem responses to climatic variability. Climate Variability and Change in High Elevation Regions: Past, Present \& Future. Springer, Dordrecht, pp.263282, https://doi.org/10.1023/A:1024427803359, 2003.

Foppa, N. and Seiz, G.: Inter-annual variations of snow days over Switzerland from 2000-2010 derived from MODIS satellite data. The Cryosphere, 6(2), p.331, https://doi.org/10.5194/tc-6-331-2012, 2012.

540 Glazovskaya T.G.: Possible changes in snow and avalanche activity due to projected global warming. MGI materials of glaciological research, Iss. No. 88, pp. 70-73, 2000. (in Russian) 
The Cryosphere Discuss., https://doi.org/10.5194/tc-2019-9

Manuscript under review for journal The Cryosphere

Discussion started: 20 February 2019

(C) Author(s) 2019. CC BY 4.0 License.

Gouttevin, I., Menegoz, M., Domin, F., Krinner, G., Koven, C., Ciais, P., Tarnocai, C. and Boike, J.: How the insulating properties of snow affect soil carbon distribution in the continental pan-Arctic area. Journal of Geophysical Research: Biogeosciences, 117(G2), https://doi.org/10.1029/2011JG001916, 2012.

545 Gregow, H., Puranen, U., Venäläinen, A., Peltola, H., Kellomäki, S. and Schultz, D.: Temporal and spatial occurrence of strong winds and large snow load amounts in Finland during 1961-2000. Silva Fennica, 42(4), pp.515-534, 2008.

Groisman, P.Y., Bogdanova, E.G., Alexeev, V.A., Cherry, J.E. and Bulygina, O.N.: Impact of snowfall measurement deficiencies on quantification of precipitation and its trends over northern Eurasia. Lëd i Sneg, 54(2), pp.29-43, https://doi.org/10.15356/2076-6734-2014-2-29-43, 2014.

550 Høgda, K.A., Karlsen, S.R. and Solheim, I.: Climatic change impact on growing season in Fennoscandia studied by a time series of NOAA AVHRR NDVI data. In Geoscience and Remote Sensing Symposium, 2001, IGARSS'01, IEEE International, 3, pp. 1338-1340, https://doi.org/10.1109/IGARSS.2001.976837, 2001.

Høgda, K.A., Tømmervik, H. and Karlsen, S.R.: Trends in the start of the growing season in Fennoscandia 1982-2011. Remote Sensing, 5(9), pp.4304-4318, https://doi.org/10.3390/rs5094304, 2013.

555 Huang, X., Deng, J., Ma, X., Wang, Y., Feng, Q., Hao, X. and Liang, T.: Spatiotemporal dynamics of snow cover based on multi-source remote sensing data in China. The Cryosphere, 10(5), p.2453, https://doi.org/10.5194/tc-10-2453-2016, 2016.

Hüsler, F., Jonas, T., Riffler, M. and Musial, J.P.: A satellite-based snow cover climatology (1985-2011) for the European Alps derived from AVHRR data. The Cryosphere, 8(1), p.73, https://doi.org/10.5194/tc-8-73-2014, 2014.

IPCC: Climate Change 2014: Impacts, Adaptation, and Vulnerability. Part A: Global and Sectoral Aspects. Contribution of Working Group II to the Fifth Assessment Report of the Intergovernmental Panel on Climate Change [Field, C.B., V.R. Barros, D.J. Dokken, K.J. Mach, M.D. Mastrandrea, T.E. Bilir, M. Chatterjee, K.L. Ebi, Y.O. Estrada, R.C. Genova, B. Girma, E.S. Kissel, A.N. Levy, S. MacCracken, P.R. Mastrandrea, and L.L. White (eds.)]. Cambridge University Press, Cambridge, United Kingdom and New York, NY, USA, 1132 pp, 2014.

Karlsen, S.R., Høgda, K.A., Wielgolaski, F.E., Tolvanen, A., Tømmervik, H., Poikolainen, J. and Kubin, E.: Growing-season 565 trends in Fennoscandia 1982-2006, determined from satellite and phenology data. Climate Research, 39(3), pp.275-286, https://doi.org/10.3354/cr00828, 2009.

Keller, F., Goyette, S. and Beniston, M.: Sensitivity analysis of snow cover to climate change scenarios and their impact on plant habitats in alpine terrain. Climatic Change, 72(3), pp.299-319, https://doi.org/10.1007/s10584-005-5360-2, 2005.

Kitaev L.M., Volodicheva N.A., and Oleynikov A.D. Long-term snow dynamics in the north-west of the Russian plain. The materials of glaciological research, 102, pp.65-72, 2007.

Koroleva, N.E.: Phytosociological survey of the tundra vegetation of the Kola Peninsula, Russia. Journal of Vegetation Science, 5(6), pp.803-812, https://doi.org/10.2307/3236195, 1994.

Kozlov, M.V. and Berlina, N.G.: Decline in length of the summer season on the Kola Peninsula, Russia. Climatic Change, 54(4), pp.387-398, https://doi.org/10.1023/A:1016175101383, 2002. 
The Cryosphere Discuss., https://doi.org/10.5194/tc-2019-9

Manuscript under review for journal The Cryosphere

Discussion started: 20 February 2019

(c) Author(s) 2019. CC BY 4.0 License.

Lawrence, D.M. and Slater, A.G.: A projection of severe near-surface permafrost degradation during the 21st century. Geophysical Research Letters, 32(24), https://doi.org/10.1029/2005GL025080, 2005.

Lemke, P., Ren, J., Alley, R.B., Allison, I., Carrasco, J., Flato, G., Fujii, Y., Kaser, G., Mote, P., Thomas, R.H. and Zhang, T.: Observations: changes in snow, ice and frozen ground. Climate Change 2007: The Physical Science Basis. Contribution of Working Group I to the Fourth Assessment Report of the Intergovernmental Panel on Climate Change. Cambridge University Press, Cambridge, United Kingdom and New York, NY, USA, 1132 pp, 2007.

Liston, G.E.: Representing subgrid snow cover heterogeneities in regional and global models. Journal of climate, 17(6), pp.1381-1397, https://doi.org/10.1175/1520-0442(2004)017<1381:RSSCHI>2.0.CO;2, 2004.

Malnes, E., Karlsen, S.R., Johansen, B., Bjerke, J.W. and Tømmervik, H.: Snow season variability in a boreal-Arctic transition area monitored by MODIS data. Environmental Research Letters, 11(12), p.125005, https://doi.org/10.1088/17489326/11/12/125005, 2016.

Marshall, G.J., Vignols, R.M. and Rees, W.G.: Climate change in the Kola Peninsula, Arctic Russia, during the last 50 years from meteorological observations. Journal of Climate, 29(18), pp.6823-6840, https://doi.org/10.1175/JCLI-D-16-0179.1, 2016.

Matsumura, S., Zhang, X. and Yamazaki, K.: Summer Arctic atmospheric circulation response to spring Eurasian snow cover 590 and its possible linkage to accelerated sea ice decrease. Journal of Climate, 27(17), pp.6551-6558, https://doi.org/10.1175/JCLI-D-13-00549.1, 2014.

Molotch, N.P., Blanken, P.D., Williams, M.W., Turnipseed, A.A., Monson, R.K. and Margulis, S.A.: Estimating sublimation of intercepted and sub-canopy snow using eddy covariance systems. Hydrological Processes, 21(12), pp.1567-1575, https://doi.org/10.1002/hyp.6719, 2007.

595 Olofinskaya, N., Dobrolyubova, J., Berdin, V., Gershinkova, D. and Masloboyev, V.: Integrated Climate Change Strategies for Sustainable Development of Russia’s Arctic Regions (Case Study for Murmansk oblast). Summary, 2009.

Peng, S., Piao, S., Ciais, P., Friedlingstein, P., Zhou, L. and Wang, T.: Change in snow phenology and its potential feedback to temperature in the Northern Hemisphere over the last three decades. Environmental Research Letters, 8(1), p.014008, https://doi.org/10.1088/1748-9326/8/1/014008, 2013.

600 Robinson, D.A., Dewey, K.F. and Heim Jr, R.R.: Global snow cover monitoring: An update. Bulletin of the American Meteorological Society, 74(9), pp.1689-1696, https://doi.org/10.1175/1520-0477(1993)074<1689:GSCMAU>2.0.CO;2, 1993.

Robinson, D.A. and Frei, A.: Seasonal variability of Northern Hemisphere snow extent using visible satellite data. The Professional Geographer, 52(2), pp.307-315, https://doi.org/10.1111/0033-0124.00226, 2000.

605 Roshydromet: Strategic forecast of climate changes in the Russian Federation for the period until 2010-2015 and their influence on Russian economic sectors. Moscow. Roshydromet, 2005. (the document is available at the Roshydromet web-site http://meteorf.ru)

Salomonson, V.V. and Appel, I.: Estimating fractional snow cover from MODIS using the normalized difference snow index. Remote sensing of environment, 89(3), pp.351-360, https://doi.org/10.1016/j.rse.2003.10.016, 2004. 
The Cryosphere Discuss., https://doi.org/10.5194/tc-2019-9

Manuscript under review for journal The Cryosphere

Discussion started: 20 February 2019

(c) Author(s) 2019. CC BY 4.0 License.

610 Sapunov VN, Seliverstov Yu.G., Troshkina E.S., Chernous P.A.: Temperature regime of air in winter seasons and its influence on avalanche activity in the Khibiny. Cryosphere of the Earth, volume X., No. 4., pp.68-73, 2006. (in Russian)

Serreze, M.C., Barrett, A.P., Stroeve, J.C., Kindig, D.N. and Holland, M.M.: The emergence of surface-based Arctic amplification. The Cryosphere, 3(1), p.11, 2009.

Serreze, M.C. and Barry, R.G.: Processes and impacts of Arctic amplification: A research synthesis. Global and Planetary Change, 77(1), pp.85-96, https://doi.org/10.1016/j.gloplacha.2011.03.004, 2011.

Shmakin, A.B.: Climatic characteristics of snow cover over North Eurasia and their change during the last decades. Ice and Snow, 1(1), pp.43-57, 2010.

Singh, P.R. and Gan, T.Y.: Retrieval of snow water equivalent using passive microwave brightness temperature data. Remote Sensing of Environment, 74(2), pp.275-286, https://doi.org/10.1016/S0034-4257(00)00121-8, 2000.

620 Storvold, R., Malnes, E., Larsen, Y., Høgda, K.A., Hamran, S.E., Mueller, K. and Langley, K.A.: SAR remote sensing of snow parameters in norwegian areas-Current status and future perspective. Journal of Electromagnetic Waves and Applications, 20(13), pp.1751-1759, https://doi.org/10.1163/156939306779292192, 2006.

Tedesco, M.: Remote sensing of the cryosphere. John Wiley \& Sons, https://doi.org/10.1002/9781118368909, 2015.

Tedesco, M. and Monaghan, A.J.: An updated Antarctic melt record through 2009 and its linkages to high-latitude and tropical climate variability. Geophysical Research Letters, 36(18), https://doi.org/10.1029/2009GL039186, 2009.

Trujillo, E., Molotch, N.P., Goulden, M.L., Kelly, A.E. and Bales, R.C.: Elevation-dependent influence of snow accumulation on forest greening. Nature Geoscience, 5(10), p.705, https://doi.org/10.1038/ngeo1571, 2012.

Troshkina E.S., Sapunov VN, Seliverstov Yu.G., Chernous P.A. Dynamics of the snow cover in the Khibiny Mountains (19362002). MGIM Materials of glaciological research, 99, pp.112-115, 2005. (in Russian)

630 Troshkina ES, Seliverstov Yu.G., Mokrov EG, Sapunov VN, Chernous PA, Solovyev A.Yu: Influence of climatic conditions change on nival-glacial processes in the Khibiny Mountains. Bulletin of Moscow University, Series 5: Geography, pp.26-32, 2009. (in Russian)

Vajda, A., Venalainen, A., Hanninen, P. and Sutinen, R.: Effect of vegetation on snow cover at the northern timberline: a case study in Finnish Lapland. Silva Fennica, 40(2), p.195, 2006.

635 Vavrus, S.: The role of terrestrial snow cover in the climate system. Climate Dynamics, 29(1), pp.73-88, https://doi.org/10.1007/s00382-007-0226-0, 2007.

Vikulina MA Assessment of avalanche activity, hazard and risk (with the Khibiny Mountains as an example). In Glaciology in the Beginning of the 21st Century (Proceedings of the International Scientific Conference). Moscow State University Publication: ed., University Book, p.260, 2009. (in Russian)

640 Walland, D.J. and Simmonds, I.: North American and Eurasian snow cover co-variability. Tellus A, 49(4), pp.503-512, https://doi.org/10.1034/j.1600-0870.1997.t01-3-00007.x, 1997. 
The Cryosphere Discuss., https://doi.org/10.5194/tc-2019-9

Manuscript under review for journal The Cryosphere

Discussion started: 20 February 2019

(c) Author(s) 2019. CC BY 4.0 License.

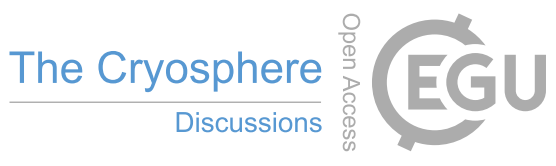

(c) (i)

Wuttke, S., Seckmeyer, G. and König-Langlo, G.: Measurements of spectral snow albedo at Neumayer, Antarctica. Annales Geophysicae 24, Nr. 1, http://dx.doi.org/10.5194/angeo-24-7-2006, 2006.

Yakovlev, B.A.: Climate of Murmansk region. Murmansk Knizhn Izd, Murmansk, 1961. (in Russian)

645 Zaika Yu.V., Vikulina M.A., Chernous P.A.: Long-term dynamics of nival processes in the Khibiny, 2013. (in Russian)

Zhang, M., Lai, Y., Liu, Z. and Gao, Z.: Nonlinear analysis for the cooling effect of Qinghai-Tibetan railway embankment with different structures in permafrost regions. Cold Regions Science and Technology, 42(3), pp.237-249, https://doi.org/10.1016/j.coldregions.2005.02.003, 2005.

Zhang, Y., Yan, S. and Lu, Y.: Snow cover monitoring using MODIS data in Liaoning Province, Northeastern China. Remote 650 Sensing, 2(3), pp.777-793, https://doi.org/10.3390/rs2030777, 2010.

Zyuzin Yu.L. The severe face of Khibiny, Murmansk. Advertising Polygraphy, pp.235, 2006. (in Russian) 
The Cryosphere Discuss., https://doi.org/10.5194/tc-2019-9

Manuscript under review for journal The Cryosphere

Discussion started: 20 February 2019

(c) Author(s) 2019. CC BY 4.0 License.

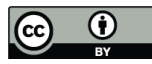

\section{Appendix}
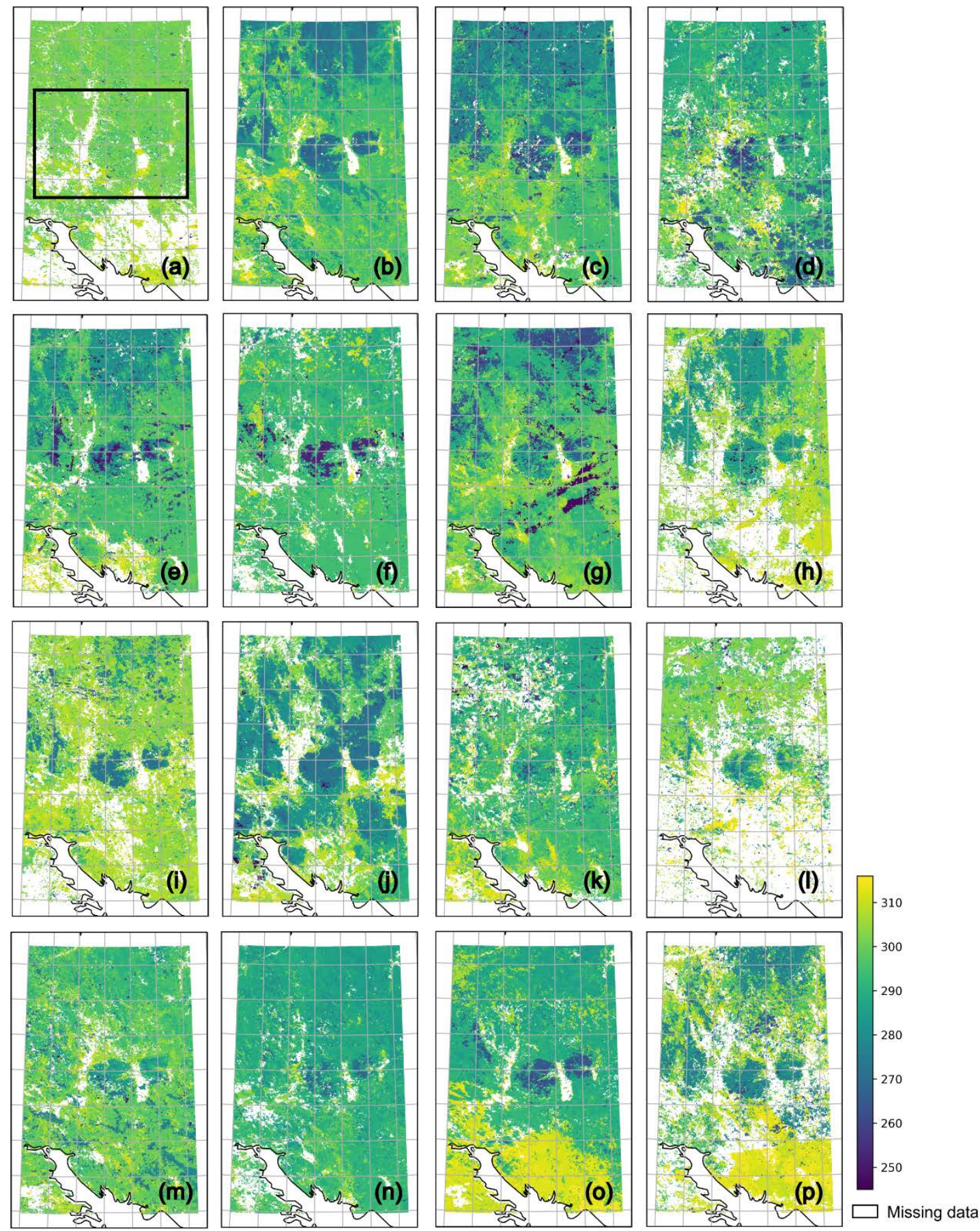

655 Figure A1: SCS maps for the WMR showing the last day of the snow-free season from the year 2000 (a) to 2015 (p). The colourbar shows the day of the year. The WMR is outlined in (a) for scale. 
The Cryosphere Discuss., https://doi.org/10.5194/tc-2019-9

Manuscript under review for journal The Cryosphere

Discussion started: 20 February 2019

(c) Author(s) 2019. CC BY 4.0 License.
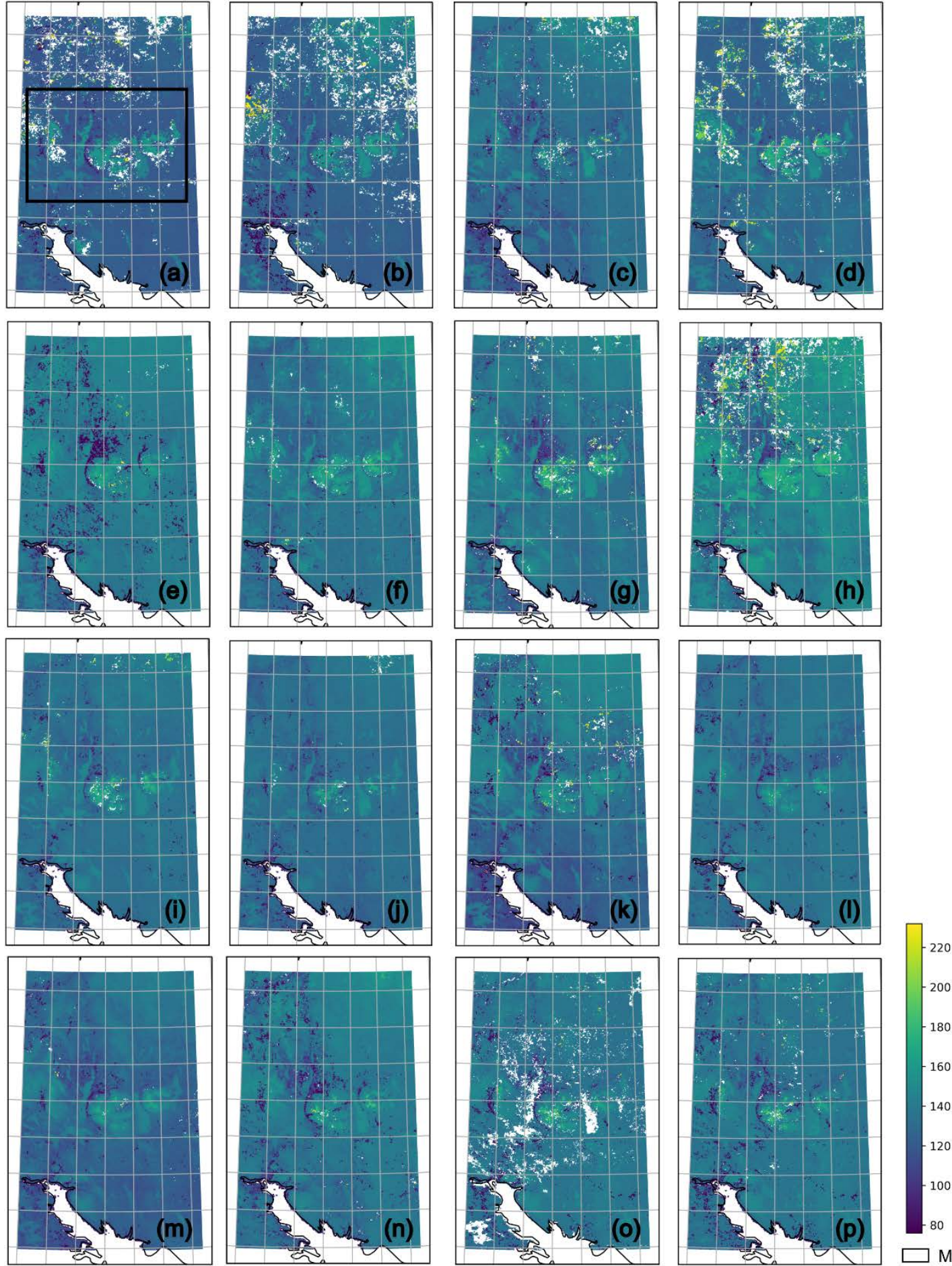

Figure A2: SCE maps for the WMR showing the first day of the snow-free season from the year 2001 (a) to 2016 (p). The colourbar shows the day of the year. The WMR is outlined in (a) for scale. 
The Cryosphere Discuss., https://doi.org/10.5194/tc-2019-9

Manuscript under review for journal The Cryosphere

Discussion started: 20 February 2019

(c) Author(s) 2019. CC BY 4.0 License.
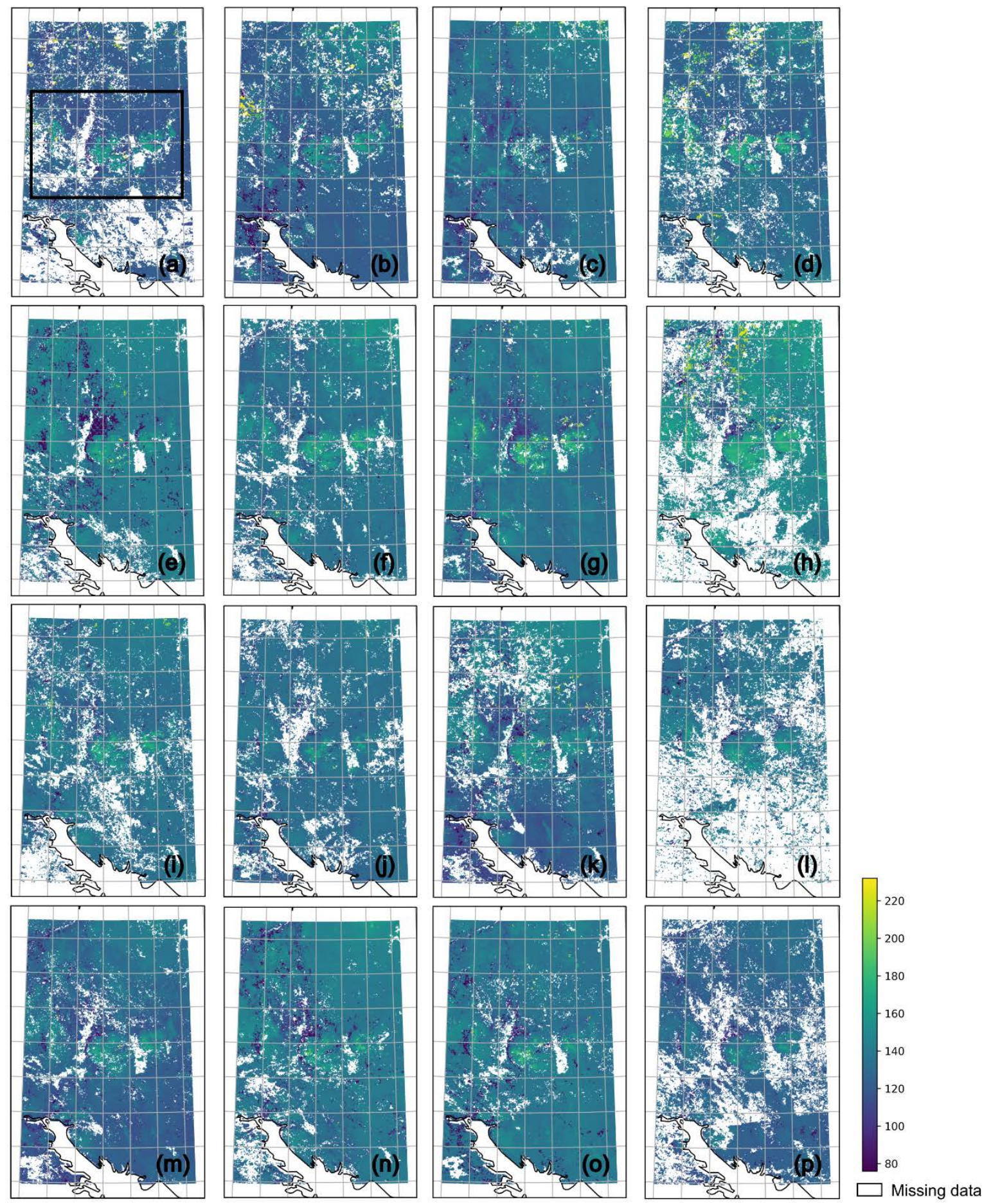

Figure A3: SCD maps for the WMR showing the duration of the snow season from the snow year 2000/2001 (a) to 2015/2016 (p). The colourbar shows the number of days. The WMR is outlined in (a) for scale. 